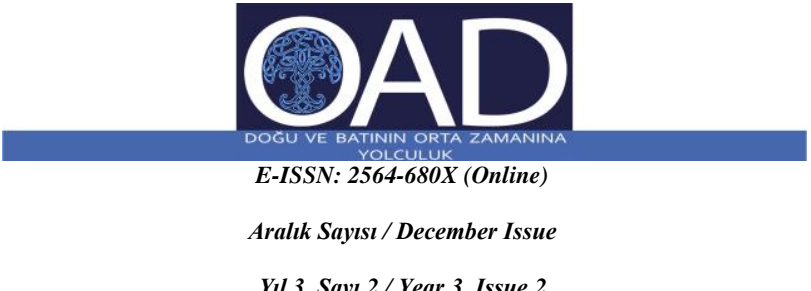

ATIF BILLGISI / REFERENCE INFORMATION

KAYA ZENBİLĊ, İlkgül, “Aziz Demetrios: Selanik’in Koruyucu Azizi, Yaşam Öyküsü ve Mucizeleriyle İlişkili Belgeler, Kültü ve Tasvirleri”, Ortaçağ Araştırmaları Dergisi, III/II, Aralık 2020, s. 361-382

Makale Türü: Sanat Tarihi Araştırma

DOI No: https://doi.org/10.48120/oad.823019

Gelis Tarihi / Received: 7 Kasım 2020 Online Yayın: 26 Aralık 2020
Kabul Tarihi / Accepted: 27 Kasım 2020

Published Online: 26 December 2020

\title{
Aziz Demetrios: Selanik’in Koruyucu Azizi, Yaşam Öyküsü ve Mucizeleriyle İlişkili Belgeler, Kültü ve Tasvirleri İlkgül KAYA ZENBİLCI ${ }^{1{ }^{*+}}$
}

${ }^{1}$ Dr. Öğr. Üyesi, Yozgat Bozok Üniversitesi Fen-Edebiyat Fakültesi, Sanat Tarihi Bölümü, YOZGAT.

*ilkgulkaya@yahoo.com

+ORCID: 0000-0001-8106-656X

$\ddot{O}_{z}-\mathrm{Bu}$ çalışmada Selanik kentinin koruyucu azizi, Aziz Demetrios'un, Bizans hagiografik yazını eşliğinde yaşam öyküsü, mucizeleri, kültü ve tasvirleri ele alınmıştır. Aziz Demetrios Bizans dini yazınında en erken 7. yüzyılda Selanik başpiskoposu Ioannes tarafından yazılan "Aziz Demetrios'un Mucizeleri”"nde karşımıza çıkar. Ancak azizin biyografisine dair 9. yüzyıla kadar bilgi yoktur. 9. yüzyıldan itibaren Demetrios'un yaşam öyküsünün üç versiyonu ortaya çıkar.

Aziz Demetrios, geleneksel anlatıya göre Selanikli ve senatör sınıfına mensup bir ailenin oğludur. 4. yüzyılın başlarında Roma imparatoru Maksimianus'un emriyle öldürülür. 6. yüzyılda kentin valisi Leontios'un amansız hastalığından mucizevî olarak kurtuluşunu Aziz Demetrios'a atfetmesi sonrasında, Demetrios'un bedeninin gömülü olduğu kabul edilen yere, Leontios'un girişimiyle bir kilise inşa edilir. Yapı 603 'ten sonra/649'dan önce, bölgede meydana gelen bir deprem sonrasında yangın geçirir. Ardından orijinal plan şeması korunarak II. Iustinianos'un 688/689 yılları civarındaki kenti ziyareti sırasında yeniden inşa edilir. Yapının ilk evresi, yazılı kaynaklar ve arkeolojik kanıtlara göre 6. yüzyılın başlarını işaret etmektedir.

Aziz Demetrios Bizans dönemindeki tasvirlerinde sivil ve asker olmak üzere iki temel tipte temsil edilmiştir. Azizin tasvirleri anıtsal duvar mozaikleri ve resimlerinde, rölyeflerde, ikonalarda, el yazmalarında, sikkelerde, mühürlerde, koutrouvialarda (hacı matarası), enkolpionlarda ve geç dönemde sırlı seramikler üzerinde yer alır. Aziz Demetrios 11. yüzyıldan itibaren, yaygın olarak, asker aziz olarak betimlenmiştir.

Anahtar Kelimeler-Aziz Demetrios, asker aziz, Selanik, hagiografi, kült

\section{St. Demetrios: The Patron Saint of Thessaloniki, The Sources Related to His Life Story and Miracles, Cult and Images}

Abstract-In this study, the protector saint of Thessaloniki, St. Demetrios's life story, his miracles, cult and depictions are discussed in the context of the Byzantine hagiographic literature. In the Byzantine theological literature, St. Demetrios first appeared in the "Miracula of Saint Demetrios" written by Archbishop John of Thessaloniki in the 7th century. However, there is no information about the saint's biography until the 9th century. Three versions of Demetrios's life story emerged from the 9th century onwards.

According to the traditional narrative, St. Demetrios was the son of a senatorial class family from Thessaloniki. He was killed on the orders of the Roman emperor Maximianus at the beginning of the 4th century. In the 6th century, after the eparkhos of Thessaloniki attributed his miraculous recovery from his disease to St. Demetrios, with Leontios's initiative, a church was built in the place where the body of Demetrios was considered to be buried. The monument suffered a fire after an earthquake that occurred in the region after 603 or before 649. Then, preserving the original plan, it was rebuilt during Iustinianos's visit to the city in 688/689. The first phase of the building points to the beginning of the 6th century, based on written sources and archaeological evidence.

St. Demetrios is presented in two basic types in Byzantine art, as a civilian or a soldier. The saint is seen in the wall mosaics and frescoes, reliefs, manuscript illuminations, icons, coins, seals, koutrouvia (pilgrim flask), enkolpia and later glazed ceramics. He was widely depicted as a soldier-saint from the 11th century onwards.

Keywords - St. Demetrios, soldier saint, Thessaloniki, hagiography, cult 


\section{Aziz Demetrios: Selanik'in Koruyucu Azizi, Yaşam Öyküsü, Mucizeleri ve İlișkili Belgeler}

Demetrios Doğu Hıristiyanlığında önce Ortodoks-Bizans toplumunda ve daha sonra Balkanlardaki Slav halklar arasında; Katolik dünyasında ise 11. yüzyıldan itibaren kabul ve saygı görmüs bir asker azizdir. Azizin hayatının nerede geçtiği ve nerede şehit edildiği konusu 7.-15. yüzyıllar arasında azize dair kaleme alınan belgeler 1şığında çeşitli yayınlarda tartışılmıştır.

Geleneksel anlatıya göre, Aziz Demetrios refah içinde yaşayan Selanikli (Thessaloniki) Hıristiyan bir ailenin oğluydu ve aile senatör sınıfına mensuptu. ${ }^{1}$ Hıristiyanlara karşı uygulanan baskı ve zulümden, Roma ordusunda asker olmasına rağmen, Hıristiyanlığ 1 seçmiş olması nedeniyle Demetrios da nasibini almıştı.

4. yüzyılın başında, imparator Maksimianus'un ${ }^{2}$ (286-305) Selanik'te olduğu sırada, Demetrios halk arasında Hiristiyan doktrinini yaymaktaydı. Bir gün Demetrios kent stadyumuna ${ }^{3}$ giden Maksimianus'un huzuruna götürüldü. İmparator, yapılacak bir gösteri için Demetrios'un halk hamamında tutulmasını emretti. Özellikle Lyeus adlı bir gladyatörle ilgilenen imparator, gladyatör gösterisinde tarafını tuttuğu Lyeus ile dövüsecek olan kișiye ödül vereceğini söyledi. Bu sırada Nestor adında bir genç kendini tanıttı. İmparator, Lyeus'un kazanacağından emin olduğu için, Nestor'u dövüşten vazgeçirmeyi denedi. Ancak Nestor tutumunda israr etti ve Lyeus'la dövüşerek onu öldürdü. Öfkelenen imparatora, hamamda tutulmakta olan Demetrios hatırlatıldı. İmparator, Demetrios'un mızrakla öldürülmesini emretti ve azizin cesedi, işkencenin gerçekleştiği yere gömüldü. ${ }^{4}$

Bazı modern kaynaklar Demetrios'un Selanik'teki Helenistik agorada, Khalkeutiki stoasında tutuklanarak, ardından halk hamamında şehit (martyr) edildiğini; ${ }^{5}$ Romalıların Hıristiyanlara karşı takındığı tutum nedeniyle Demetrios'un bedeninin Selanik'teki Hıristiyanlar tarafindan gizlice defnedildiğini; Milano Ferman sonrasında Selanik'teki Roma hamamının bir bölümüne bir oda (oikiskos ya da martyrion) eklenerek azizin naaşının buraya gömüldüğüne inanıldığını vurgular. $^{6}$ Aslında Demetrios'un öldürüldüğü yer belirsizdir.?
Aziz Demetrios'un Selanik’te şehit edilmediğini kabul eden görüş; yaklaşık 362'de Nikomedia'da derlenen "Martyrologium Hieronymianum" adlı Yunanca esere dayalı olarak kaleme alınan "Süryani Breviariumu"nu temel alır. Bu eser günümüze gelen, en erken tarihli şehitlik derlemesidir (martyroloji) ve 411/412 y1lları civarına aittir. Ancak geniş Balkan coğrafyasında ölen şehit ve şehit gruplarına ilişkin çok sayıda anlatı içeren bu eserde, Selanik'te şehit olan herhangi bir "Demetrios"tan bahsedilmez. Süryani Breviariumu'nun Yunanca orijinal versiyonuna bağlı görünen, Kuzey İtalya'da 431-450 dolaylarında yazıldığı anlaşılan "sözdeMartyrologium Hieronymianum"da da Demetrios'tan söz edilmemektedir. Bu metinlere bakılırsa; metinler Aziz Demetrios'un Selanik'te ölmediğini kanıtlamakla kalmaz; aynı zamanda azizin kültünün ortaya çıkışına neden olan her ne ise, bunun 362 'den sonra gerçekleşmiş olduğunu da ortaya koyar. ${ }^{8}$

Bu görüşü aynı zamanda Selanik'teki Aziz Georgios Rotondu (G.12) olarak adlandırılan yapı üzerinden de desteklemek mümkündür. Yapının kubbe eteğindeki anıtsal mozaiklerde gruplar halinde betimlenen, 15 'i günümüze gelebilmiș, 16 azizin tamamı, hagiografik kaynaklarda kaydedilen şehitlerle (martyr) net bir biçimde ilişkilendirilememiştir. ${ }^{9}$ En önemli nokta ise bu figürler arasında Demetrios'un yer almaması ve figürleri tanımlayan kitabelerden birinin günümüze gelmemiş olması nedeniyle, aziz figürlerinden birinin anonim kalmasıdır. Eğer yapı S. Ćurčić, C. Bakirtzis ve P. Mastora'nın kabul ettiği üzere; I. Konstantinos'un (306-337) ölümünün (337) hemen ardından inşa ettirilip, aynı dönemde mozaiklerle dekore edilmiş bir Hıristiyanlık yapısı ise, Demetrios'un 4. yüzyılın başlarında Selanik'te şehit edilip, kentte azizin kültünün bu dönemde yayılmaya başladığı görüşü kabul edildiğinde, rotonddaki 16 martyr arasında neden Demetrios'un yer almadığını açıklamak pek de kolay olmayacaktır. ${ }^{10}$

Aziz Georgios Rotondu'nun mozaikleri farklı araştırmacılar tarafından farklı dönemlere tarihlenir. Örneğin; E. Dyggve I. Theodosios dönemini önermektedir. ${ }^{11}$ G. Matthiae rotondun mozaiklerini 400-425 yılları arasına tarihlerken;12 M. Vickers 430450 yılları arasını kabul eder. ${ }^{13}$ W. E. Kleinbauer $450-475$ arasın $1{ }^{14}$ E. Weigand 6. yüzyılın ilk-ikinci yarısı civarını ileri sürmektedir. ${ }^{15}$
1 P. Lemerle, "Note sur les plus anciennes représentations de Saint

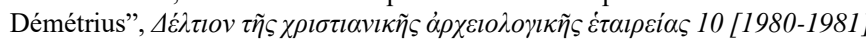

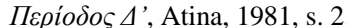

${ }^{2}$ Aurelius Valerius Maksimianus, M.S. 286-305 y1lları arasında Diokletianus ile müşterek imparatordur, bkz.; A. Pasqualini, Massimiano Herculius Per Un'interpretazione della Figura e dell'Opera, Roma, 1979. M. Vickers bir makalesinde Maksimianus'un değil, Galerius'un adını verir; M. Vickers, "Sirmium or Thessaloniki? A Critical Examination of The St. Demetrius Legend", Byzantinische Zeitschrift 67(2), 1974, s. 341.

3 Stadyuma iliskin bkz.; M. Vickers, "The Stadium at Thessaloniki", Byzantion 41, 1971, s. 339-348.

${ }^{4}$ H. Delehaye, Les Légendes Gresques des Saints Militaires, Paris, 1909; s. 104. Bu anlatının Vatikan Kütüphanesi'nde bulunan Vat. gr. 821 envanter numaralı eserde başka bir versiyonu vardır. Esere makalemizde değinilmektedir.

5 E. Koukourtidou-Nikolaidou ve A. Tourta, Wandering in Byzantine Thessaloniki, Kapon Editions, Atina, 1997, s. 153. Hellenistik dönem kentine ilișkin bkz.; M. Vickers, "Hellenistic Thessaloniki", The Journal of Hellenic Studies 92, 1972, s. 156- 170.

${ }^{6}$ Koukourtidou-Nikolaidou ve Tourta, Byzantine Thessaloniki, s. 153.

${ }^{7}$ P. Magdalino, "Saint Demetrios and Leo VI", Byzantinoslavica LI(2), 1990 s. 198.

${ }^{8}$ D. Woods, “Thessalonica's Patron: Saint Demetrius or Emeterius?", The Harvard Theological Review 93/3, 2000, s. 221-222.

9 "Yapıdaki azizlerin hepsinin Doğulu azizler olduğu ve çoğunluğunun Diokletianus döneminde yapılan zulümler sirasında şehit edildiği konusunda genel bir fikir birliği vardır. Mozaiklerdeki figürler meslek ve rütbe gösteren kıyafetler içinde temsil edilmişlerdir ve böylece bir aziz sınıfinı diğerinden ayırmaya yardımcı olur: askerler beyaz veya mor khlamys giyerler, siviller, laikler ve benzer şekilde din adamlarl beyaz veya mor paenula kuşanmişlardır. Bu kutsal figürler, askerler ve siviller, rahipler ve piskoposlar, bir hizmetkâr, bir flütçü ve iki doktordan oluşur. Tasvirlerdeki figürleri teşhis etmeyi ve bir istisna dışında azizleri mesleklerine göre ayırmayı olanaklı kılan en önemli kanıt yazıtlardır. Her bir figürün yanında azizin adl, mesleği ve anma ayl kayltlıdır. Örneğin Onesiphoros-askerAğustos, Damianos-doktor-Eylül, Philippos-piskopos-Ekim gibi.”; B. Kiilerich, "Picturing Ideal Beauty: The Saints in The Rotunda at Thessaloniki", An Tard 15, 2007, s. 322. Tasvirlerdeki figürler için bkz.; a.g.e., s. $323 \mathrm{vd}$.

${ }^{10}$ S. Ćurčić'e göre Rotond I. Konstantinos'un (306-337) mezar yapısı olarak inşa edilmiştir; S. Curčić, Some Observations and Questions Regarding Early Christian Architecture in Thessaloniki, Ephoreia of Byzantine Antiquities of Thessaloniki, Selanik, 2000, s. 11-14. Bakirtzis ve Mastora yapının mozaiklerine ilișkin imparator I. Konstantinos dönemini önerir; C. Bakirtzis, ve P. Mastora, "Are the mosaics in the Rotunda in Thessaloniki linked to its conversion into a Christian church?", IX. International Symposium 'Niš and Byzantium', Niš, 3-5 June 2010, Niš, 2011, s. 33-45.

${ }^{11}$ E. Dyggve, Recherches sur le Palais Impérial de Thessaloniki, Kopenhag, 1953, s. 59-70.

${ }^{12}$ G. Matthiae, "La cultura figurativa di Salonicco nei secoli V e VI", Rivista di Archeologia Cristiana 38, 1963, s. 196-199.

${ }^{13}$ M. Vickers, "The Date of the Mosaics of the Rotunda at Thessaloniki", Papers of The British School in Rome 38, 1970, s. 183-187.

${ }^{14}$ W. E. Kleinbauer, "The Iconography and the Date of the Mosaics of the Rotunda of Hagios Georgios, Thessaloniki”, Viator 3, 1972, s. 27-108.

15 E. Weigand, "Der Kalenderfries von Hagios Georgios in Thessaloniki. Datierung, Ideen-und Kunstgeschichtliche Stellung", Byzantinische Zeitschrift 39, 1939, s. 116-145. 


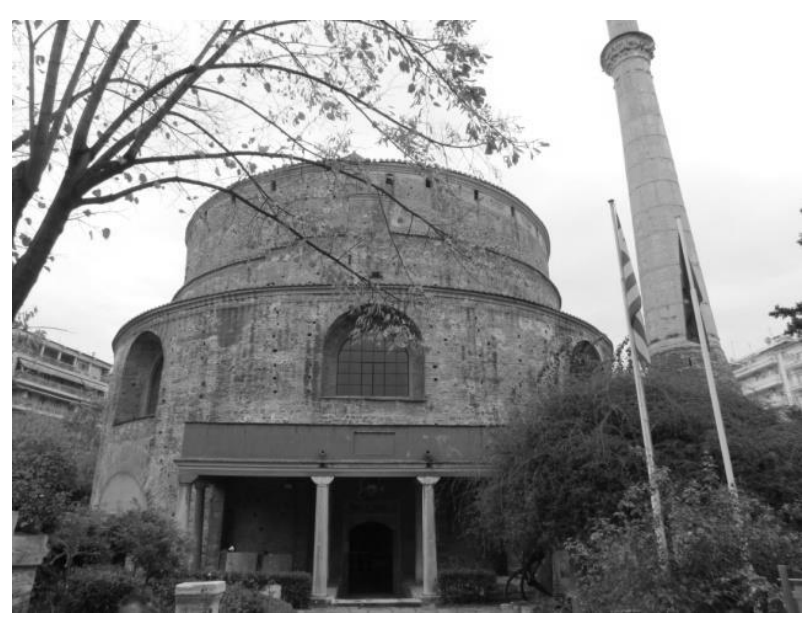

G.1.Aziz Georgios Rotondu, batı girişi, Selanik, Yunanistan (Foto. yazara ait, 2018).

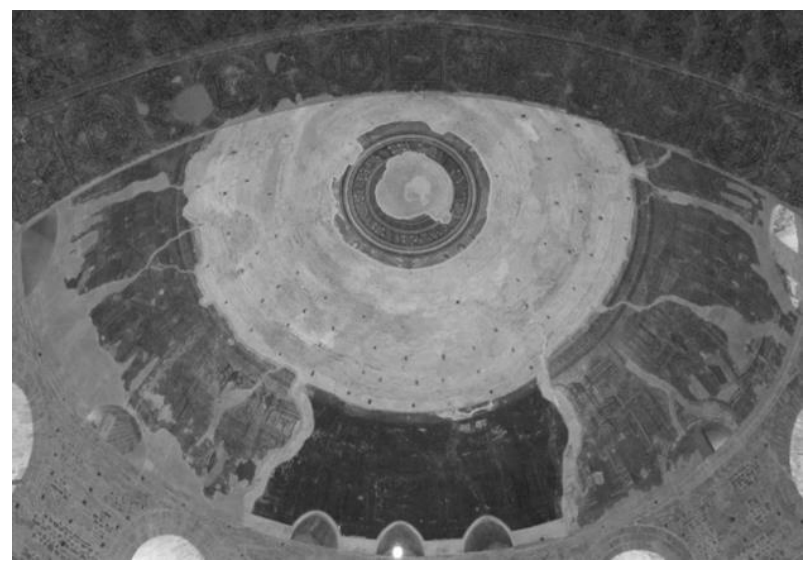

G.2.Aziz Georgios Rotondu, kubbe, Selanik, Yunanistan (Foto. yazara ait, 2018).

Aziz Demetrios Kilisesi'nin inşa hikâyesinin, azizin yaşam öyküsü ve mucizelerine ilişkin, aşağıda ele alınan belgelere dayanması; yapının gerçekten kime adandığı konusunda şüpheye yer bırakmaz. Yapı, 5. yüzyılda amansız bir hastalığa yakalanan İlirya (Illyricum) themasının valisi (eparkhos ${ }^{16}$ ya da praefectus praetorio per Illyricum) olduğu düşünülen Leontios'un, mucizevî bir şekilde iyileşmesini azize atfetmesi sonrasında, Roma hamamının bulunduğu yere, Leontios'un girişimiyle inşa edilir. ${ }^{17}$ Delehaye; "şayet Leontios şehidin onuruna bir bazilika inşa etmişse, bunun nedeni kendisinden mucizevî bir iyilik görmüş olmasıdır." demektedir. ${ }^{18}$

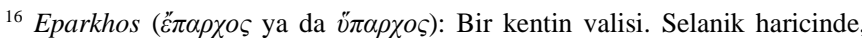
yalnızca Geç Roma Dönemi'ne kadar kullanılmış bir unvandır. A. Kazhdan, "Eparch", Oxford Dictionary of Byzantium I, (ed. A. P. Kazhdan), Oxford University Press, Oxford, 1991, s. 704.

17 Delehaye, Les Légendes Gresques, s. 104; 105-106; KoukourtidouNikolaidou ve Tourta, Byzantine Thessaloniki, s. 153.

${ }^{18}$ Delehaye, Les Légendes Gresques, s. 106.

${ }^{19}$ A. Alföldi, Der Untergang der Römerherrschaft in Pannonien II, Berlin, Leipzig, 1926, s. 96; P. Tóth, "Sirmian Martyrs in Exile Pannonian CaseStudies and Re-evaluation of The St. Demetrius Problem", Byzantinische Zeitschrift 103(1), 2010, s. 166.

${ }^{20}$ Vickers, "Sirmium or Thessaloniki", s. 346-350; Tóth, "Sirmian Martyrs", s. 166.

${ }^{21}$ Tóth, "Sirmian Martyrs", s. 166.

${ }^{22}$ Sirmium: Sava Nehri'nin sol yakasında yer alan, Geç Roma Dönemi’ndeki Pannonia Secunda'nın başkenti olan yerleşimdir, bugünkü Sremska Mitrovica, bkz.; A. Kazhdan, "Sirmium", Oxford Dictionary of Byzantium III, (ed. A. P. Kazhdan), Oxford University Press, Oxford, 1991, s. 1906; D. Woods, "Constantius, Julian, and The Fall of Sirmium", Exemplaria Classica, Anejo VII, 2016, s.175-191; M. Mirković, Sirmium Its History from The First Century AD to 582 AD, Sremska Mitrovica, Novi Sad, 2017, s. 19-55.
Azizle ilişkili metinlerde adı geçen Leontios'un gerçekte kim olduğu konusu bilim dünyasını uzun zaman meşgul etmiştir. A. Alföldi, Leontios'u teşhis eder ve onun Konstantinopolis'in valisi Leontios'la özdeş olduğu sonucuna ulaşır. Söz konusu Leontios, Konstantinopolis'teki pozisyonuna terfi etmeden önce, muhtemelen, 434 civarında İlirya'nın valisi olmuş ve Alföldi'nin iddia ettiği üzere, 441'de Sirmium'u tehdit eden istilalardan kaçmak zorunda kalmıştır. Alföldi, Leontios'un Aziz Demetrios'un röliklerini Sirmium'dan Selanik'e getirdiğini de belirtir. ${ }^{19} \mathrm{M}$. Vickers, Alföldi ile aynı sonuca ulaşır. ${ }^{20}$

P. Tóth'a göre Selanik’teki kilisenin banisi Leontios, Alföldi ve Vickers'ın iddia ettiği gibi, İlirya valisi ile özdeş olamaz ve Leontius'un azizin röliklerini Sirmium'dan Selanik'e getirmesi hakkındaki tüm hipotez, geç ve görünüşe göre hatalı bir bilimsel kurgudur. Bu nedenle, kilisenin banisi olarak geriye kalan tek hak sahibi, kentin 6. yüzy1ldaki valisi Leontios'tur. Bazilika ile ilgili arkeolojik ve tarihi araştırmaların sonucuna uyan sadece bu kişidir. ${ }^{21}$

Aziz Demetrios Kilisesi'nin tarihlendirilmesindeki yanlışlığa neden olan bilgi, Leontios'un yapının inşasından sonra Sirmium'a ${ }^{22}$ dönmesi ve yerleşimin kısa bir süre sonra Hun hükümdarı Attila tarafından 441 yılında yıkılmış olmasıdır. ${ }^{23}$ Temelde buradaki sorun, kaynakların aslında 5. yüzyılın ilk yarısındaki İlirya valisinden değil, başka bir Leontios'tan söz ediyor olmasıdır. ${ }^{24}$

Araştırmacıların, Selanik'teki Aziz Demetrios Kilisesi'nin ilk evresi, yapı elemanları ve mozaikleri ile ilişkili tarihlendirmelerine baktığımızda, 5. ile 6. yüzyılların farklı dönemlerine yoğunlaşan farklı tarihlendirmeler karşımıza çıkmaktadır.

W. E. Kleinbauer'e göre yapının ilk mozaikleri, ikonografik özelliklerine dayanılarak, 450-475 yılları arasına tarihlenir. Yapıdaki çeşitli tiplerdeki sütun başlıklarından bir grup, ilk kez Suriye kiliselerinde, Qal'at Sim`ān ve Seleucia Pieria'daki, 5. yüzyılın üçüncü çeyreğinde karşımıza çıkan ve muhtemelen Konstantinopolis kökenli olan örneklere benzer. ${ }^{25}$ Kilisenin sütun başlıkları R. Kautzsch'a göre 500 y1lı civarına aittir. ${ }^{26}$ R. S. Cormack kilisenin yapımı için en kabul edilebilir tarihin 5. yüzyılın son çeyreği olduğunu belirtir. ${ }^{27}$ J.-M. Spieser ise Aziz Demetrios Kilisesi'nin 510 yılında inşa edildiğini kabul eder. ${ }^{28}$ Kilise, 603 'ten sonra ve 649 'dan önce meydana gelen bir yangında ciddi şekilde hasar görmüş ve bundan kısa bir süre sonra, kesinlikle II. Iustinianos'un 688/689 ziyareti sırasında yeniden inşa edilmiştir. ${ }^{29}$

Azizin mür (myrrhon) yağıyla ilişkili kültü yayılmadan önce, mezarının Aziz Demetrios Kilisesi'nin orta nefindeki altıgen bir kiborium içine taşındığına inanılmıştır (G.3). Söz konusu kiborium “Aziz Demetrios'un Mucizeleri” adlı eserin Birinci Kitap'ında

${ }^{23}$ O. Tafrali, Sur la date de l'église et des mosä̈ques de Saint-Démétrius de Salonique, Revue Archéologique, $4^{\text {th }}$ Series, 13, Paris, 1909, s. 99-101; Vickers, "Sirmium or Thessaloniki", s. 337.

${ }^{24}$ Aziz Demetrios'un Mucizeleri adlı eserde söz edilen unvanlar ve ayrıca İlirya hakkında bkz.; A. Gkoutzioukostas, "The prefect of Illyricum and the prefect of Thessaloniki”, Byzantiaka 30, 2012-2013, s. 45-80; özellikle s. 5253.

${ }^{25}$ W. E. Kleinbauer, "Some Observations on the Dating of S. Demetrius in Thessaloniki”, Byzantion 40, 1970, mozaikler için bkz. s. 40 ve 43-44; sütun başlıkları için bkz. s. 39 .

${ }^{26}$ R. Kautzsch, Kapitellstudien. Beiträge zu einer Geschichte des Spätantiken Kapitells im Osten vom vierten bis ins siebente Jahrhundert, Studien zur Spätantiken Kunstgeschichte, Berlin, Leipzig, 1936, s. 73-75; Vickers, "Sirmium or Thessaloniki", s. 337.

${ }^{27}$ Cormack, "Mosaic Decoration", s. 45.

28 J.-M. Spieser, Théssalonique et ses monuments du IVe au VIe siècle Contribution à l'étude d'une ville paléochrétienne, École Française d'Athènes, Paris, 1984, s. 214.

${ }^{29}$ R. S. Cormack, "The Mosaic Decoration of St. Demetrios, Thessaloniki: A Re-Examination in The Light of The Drawings W. S. George", The Annual of the British School at Athens 64, 1969, s. 45. 
anlatılmaktadır $^{30}$ ve bu eserin tarihi, kiborium için terminus post quem oluşturur. Eserde Aziz Demetrios'un mezarının kiboriumun altında olduğu şeklindeki doğrulanmamış yerel sözlü gelenek üç kez tekrarlanır. ${ }^{31}$ Orijinalde gümüş kaplı olan ahşap kiborium sonradan mermer olanıyla değiştirilmiş ve buraya olasılıkla azizin bir ikonası yerleştirilmiştir $^{32}$ (G.3)

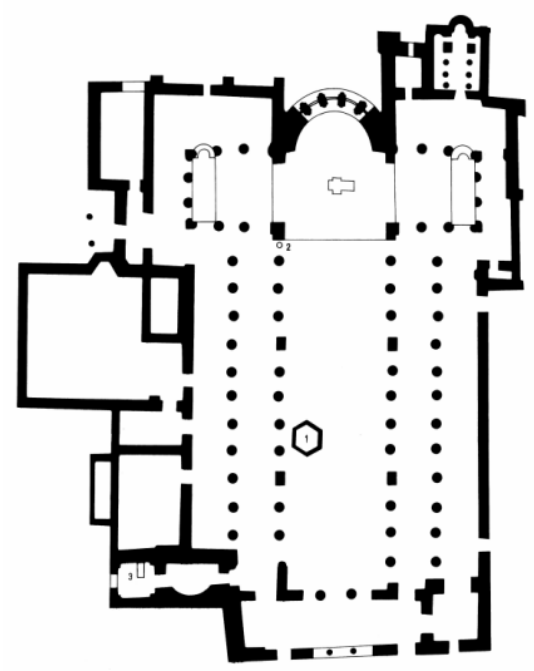

G.3. Aziz Demetrios Kilisesi planı, (1: krypta, 2: kuyu, 3: mezar), SelanikYunanistan (Bakirtzis’ten)

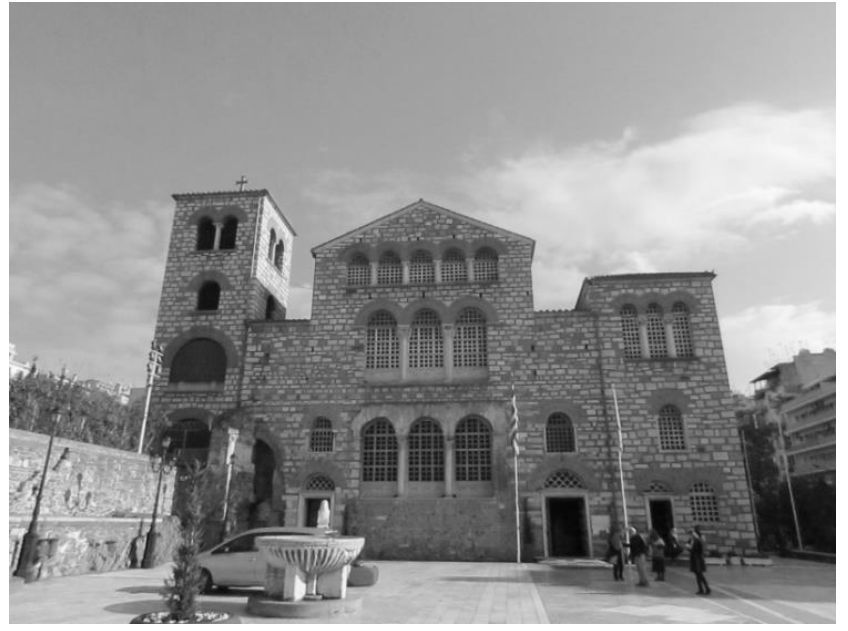

G.4. Modern dönem restorasyonu sonrasında Aziz Demetrios Kilisesi, bat cephe, Selanik, Yunanistan (Foto. yazara ait, 2018).

J. C. Skedros, Süryani Breviariumu'nun ve Breviarium'un dayandığ 1 Yunanca orijinal metnin din şehitlerinin (martyr) tam ve kapsamlı bir listesini oluşturmaması nedeniyle; 5. yüzyılın başlarında Aziz Demetrios Kilisesi’nin inşa edildiği yerde veya yakınlarında, Selanik

${ }^{30}$ P. Lemerle, Les Plus Anciens Recueils des Miracles de Saint Démétrius I: le Texte, Paris, 1979; C. Bakirtzis, "Pilgrimage to Thessalonike: The Tomb of St. Demetrios", Dumbarton Oaks Papers 56, 2002, s. 176, 178.

${ }^{31}$ Bakirtzis, "Pilgrimage to Thessalonike", s. 177.

${ }^{32}$ Koukourtidou-Nikolaidou ve Tourta, Byzantine Thessaloniki, s. 153.

${ }^{33}$ Skedros'tan aktaran: Woods, "Thessalonica's Patron", s. 222. bkz. J. C. Skedros, Saint Demetrios of Thessaloniki: Civic Patron and Divine Protector 4th- 7th Centuries CE, Trinity Press International, Harrisburg, 1999, s. 14-17.

34 Delehaye'dan aktaran: Woods, "Thessalonica's Patron”, s. 224. bkz. Delehaye, Les Légendes Gresques.

${ }^{35} \mathrm{Bu}$ kalıntılarla ilgili, piskoposların imparatorlardan aldığ $\breve{1}$ taleplere ve karşılığında verdikleri cevaba aşağıda değinilecektir.

${ }^{36}$ Woods, "Thessalonica's Patron", s. 224. kent duvarlarında şehit edilen ve bu duvarların içine gömülen tarihî bir Demetrios figürünün olduğu sonucuna varır. ${ }^{33}$ İlk şehitlik kayıtlarında Aziz Demetrios'un yokluğu, H. Delehaye tarafından Sirmium'da 9 Nisan'da şehit edilen Demetrios üzerinden açıklığa kavuşturulur. Delehaye'a göre Selanikli Aziz Demetrios'un kültü, Sirmiumlu aynı adlı azizin bazı röliklerinin Selanik'e taşınmasının bir sonucu olarak gelişmiştir. ${ }^{34}$

Bu hipotezin iki avantajı ortaya çıkmıştır: "Selanik kent surları içindeki belirgin bir yerde bulunan Aziz Demetrios için merkezî kült bölgesinin alışılmadık konumunun açıklanabilmesi" ve "kentteki ardışık piskoposların neden hiçbir zaman azizin cismani kalıntılarını üretemediğinin cevabı". ${ }^{35}$

Romalılar kentlerinin duvarları içinde Hıristiyan cenaze törenlerine izin vermedikleri için, Hıristiyanlar şehitleri de dâhil olmak üzere, ölülerini her zaman kent dışındaki mezarlıklara gömerlerdi ve böylece şehit kiliseleri normalde kent duvarlarının dışına inşa edilirdi. $\mathrm{Bu}$ durumda Aziz Demetrios'un Selanik'teki kilisesi durumunda olağandışı bir şey olduğu varsayılmadıkça, yapının konumuna bağlı olarak doğal varsayım, aslında binanın azizin orijinal mezar alanı üzerinde inşa edilmemiş olmasıydı. İkinci konuya gelinecek olursa; azizin kalıntıları zaten baştan beri Selanik piskoposlarının ellerinde bulunmamaktayd. ${ }^{36}$

Selanik'te, imparatorluğun diğer kent ve kasabalarının aksine 6.-7. yüzyıllardaki Avar ve Slav akınları karşısında, fazla tahrip olmadan, ayakta kalmaya devam eden kentin, Aziz Demetrios'un korumasi altında olduğu inanışı hâkim olmuştur; dolayısıyla bu dönemde kentte azizin kültünün varlık gösterdiği anlaşılır. Bunun en iyi kanıtı Aziz Demetrios'a ilişkin ilk sistematik belge olan, 7. yüzyılda, imparator Herakleios'un hükümranlığının (610-641) ilk yıllarında, Selanik başpiskoposu Ioannes tarafindan yazılan "Aziz Demetrios'un Mucizeleri" (Miraculo) eseridir. ${ }^{37}$

Eserde Demetrios'la ilişkili lokalizasyon, kilise ve kiboriumun tasviri ön plana çıkar. Eserdeki ikinci önemli yön azizle ilişkilendirilen mucizevî olaylardır. Aynı zamanda asker olan Demetrios, esere göre halk arasında kimi zaman beyaz renkli konsül kıyafetleriyle dolaşır ve beyaz bir ata binerdi. ${ }^{38}$ Kentin zor zamanlarında daima yanında olan imparator değil, Aziz Demetrios'tu; Selanik halkının açlık dönemlerinde kente Demetrios buğday sağlamıştı. ${ }^{39}$

Aziz Demetrios'un Mucizeleri'nde iki önemli olaydan söz edilir. İlkinde, Ioannes'in öncülü, Selanik bașpiskoposu Eusebios, imparator Maurikios'tan (582-602) azizin röliklerini talep eden bir mektup alır. Eusebios șehidin röliklerinin nerede olduğunu bilmediğini belirterek, imparatorun isteğini yerine getirmeyi nazikçe reddeder. ${ }^{40}$ Eusebios ayrıca imparator Iustinianos'un (527-565) şehidin röliklerini başkent için satın alma girişiminin başarısız olduğuna işaret eder. Bu vesileyle halktan kimi kişiler, azizin kalıntılarının bulunabileceğini düşündükleri Aziz Demetrios Kilisesi'nin bir bölümünü kazmaya başlar; ancak önlerinde bir alev belirir ve onları daha fazla

${ }^{37}$ Lemerle, "Représentations de Saint Démétrius", s. 3. Mucizelere dair bkz.; Lemerle, Les Plus Anciens Recueils des Miracles de Saint Démétrius II: Commentarie, Paris, 1981, s. 50-165. Iohannes'in metninin Modern Yunanca versiyon için bkz.; P. K.

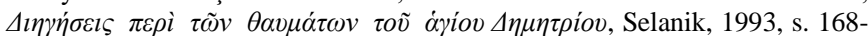
369; A. Aideri,

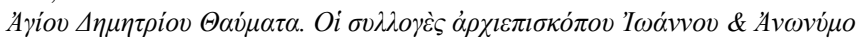
v, (ed. C. Bakirtzis), Atina, 1997, s. 50-231.

38 Lemerle, "Représentations de Saint Démétrius", s. 2-4; R. J. Macrides, "Subversion and Loyalty in The Cult of St. Demetrios", Byzantinoslavica LI(2), 1990, s.189-191.

${ }^{39}$ Macrides, "Subversion and Loyalty", s.189-191.

${ }^{40}$ Lemerle, Miracles de Saint Démétrius I, 89:20-25; Kazhdan ve Ševčenko, "Demetrios of Thessalonike", s. 605. 
kazmamaları için uyaran bir ses duyulur. Böylelikle, azizin röliklerini sahiplenmek üzere iki imparatorluk teşebbüsü önlenmiştir. ${ }^{41}$

Eusebios'un zamanındaki bir diğer mucize, Demetrios'un kentte kalma kararlılığını göstermektedir. Ioannes bu mucizeyi, Maurikios'un hükümdarlığı sırasındaki Avar ve Slav kuşatmasında şehri Demetrios'tan başka kurtaran hiç kimsenin olmadığının kanıtı olarak aktarır. Mucizeye göre;

"Bir adam kiliseye giren, imparatorun korumalarina benzeyen uzun boylu, yaklşlkl iki adam görür. İki adam efendilerinden Demetrios'un Selanik'i terk etmesini emreden bir mesaj taşıdıkların açıklarlar, çünkü şehrin düşmana terk edileceğine inanmaktadırlar. O sırada Aziz Demetrios bir süreliğine ortaya çılkar ve sonra bu isteğe itaat edemeyeceğini, çünkü halkını terk etmesinin imkânsız olduğunu söyler." $" 42$

Ioannes'in “Aziz Demetrios'un Mucizeleri” eseri 7. yüzyıldan 15. yüzyıla kadar 31 yazma eserde kopyalanmıştır. ${ }^{43} \mathrm{Bu}$ eserlerden bazıları Mucizeler'e ek olarak Demetrios'a adanan homiliye, enkomion (ya da enkomium=methiye), söylev (oratio) gibi çeşitli metinler içerir. Bugün Paris'teki Fransa Ulusal Kütüphanesi'nde yer alan bu türden derleme bir eserde, Cod. gr. 1517 envanter numaral1, 12. yüzyıla ait anonim el yazmasında, Aziz Demetrios'un yaşam öyküsü (folyo 1recto-10verso), Aziz Demetrios'un Mucizeleri eserinden alıntilar (folyo 12recto-206recto), VI. Leon'un Demetrios'a adadığı homiliyeler (folyo 206recto-208recto), yine Selanik başpiskoposu Ioannes'in kaleme aldığ 1 Aziz Demetrios'a övgüler (folyo 226recto-248recto) ve Selanik eparkhosu Ioannes'in Demetrios için yazdığ enkomionlar (folyo 248recto-253verso) yer alır. ${ }^{44}$ Eserin bir kısmında anlatılan Demetrios figürüne dair Lemerle'nin izlenimi şu şekildedir:

"Khlamys giyen Aziz Demetrios, şehre sizan barbarlarl yaya olarak ve bir sopanın darbeleriyle avlayan tehdit altındaki bir arka kapının savunucusu olarak görünür: ayn zamanda bu sahne Selanik'in Slavlara karşı savunma döngüsünün bir parçası olan, sanki bazı bașka resimlerden esinlenilmiș gibidir ve ancak Aziz Demetrios'a,

${ }^{41}$ Macrides, "Subversion and Loyalty", s.191. 688/689'da yayınlanan resmi bir imparatorluk belgesi olan II. Iustinianos'un fermanı, Aziz Demetrios'un röliklerinin Selanik'teki kilisesindeki varlığından iki kez bahsetmektedir. Bu metin, Mucizeler ile çelişmemektedir. Aksine, imparatorun Selanik'teki kilisesinin azizin röliklerine sahip çıkmayı sürdürmesi gerektiğine dair kesin görüşünü yazılı olarak belirtmesi açısından önemlidir, bkz.; J.-M. Spieser, "Inventaires en vue d'un recueil des Inscriptions Historique de Byzance I: Les Inscriptions de Thessalonique", Travaux et Mémories du Centre de Recherche d'Historie et Civilisation de Byzance 5, 1973, s. 159.

${ }_{42}$ Macrides, "Subversion and Loyalty", s.192; Magdalino, "Saint Demetrios", s. 198.

${ }^{43}$ Liste halinde incelemek için bkz.; Pinakes: Textes et Manuscrits Grecs, "Iohannes Thessalonicensis mtr. Miracula S. Demetrii", https://pinakes .irht.cnrs.fr/notices/oeuvre/9357/, 2016, [Erişim Tarihi: 19.10.2020].

${ }^{44}$ Esere ilişkin bkz.; Lemerle, Miracles de Saint Démétrius I; s. 15-19; D.

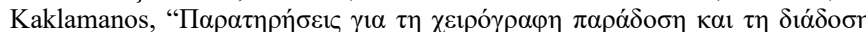

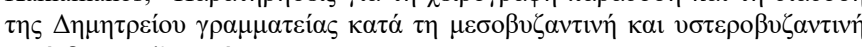

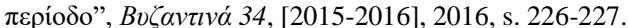

${ }^{45}$ Lemerle, "Représentations de Saint Démétrius", s. 5.

${ }^{46}$ C. de Bije, "De S. Demetrio Martyre Thessalonicæ In Macedonia Commentarius Prævius", Acta Sanctorum Octobris IV, Brüksel, 1780, s. 5052 .

${ }^{47}$ C. de Bije, "Passio Prima Ab auctore anonymo scripta atque ab Anastasio Bibliothecario è lingua Græca in Latinam conversa", Acta Sanctorum Octobris IV, Brüksel, 1780, s. 87-89.

${ }^{48}$ A. Kazhdan ve N. P. Ševčenko, "Demetrios of Thessalonike", Oxford Dictionary of Byzantium I, (ed. A. P. Kazhdan), Oxford University Press, Oxford, 1991, s. 605; T. Hägg, "Photius as a Reader of Hagiography: Selection and Criticism", Dumbarton Oaks Papers 53, 1999, s. 43.

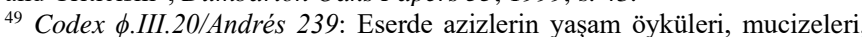
Nazianzlı Gregorios'un, Iohannes Khrysostomos'un, Stoudioslu Theodoros'un ve çeşitli kişilerin kaleme aldıkları homiliye'ler gibi çeşitli dini metinler yer alır, bkz.; E. Miller, Catalogue des manuscrits grecs de la Bibliothèque de l'Escurial, Paris, 1848, s. 180-182; S. Lucà, "Dalle collezioni zırh verilmeyerek ve bir sopadan başka silahı olmadığı için, askeraziz rolü yüklenmiştir; dahası muhtemelen düşmanın zayıfliğına dair "alaycl" tavirdan dolayı Demetrios'un zırh veya fazlasina ihtiyacı da olmamıştır."

Azizin biyografisine dair 9. yüzyıla kadar bilgi yoktur. 9. yüzyıldan itibaren Demetrios'un öyküsünün üç versiyonu ortaya çıkar. Bu edisyonlar 18. yüzyılda C. de Bije tarafından tanımlanmıştır. ${ }^{46}$ Üç versiyondan ilki Passio Prima olarak adlandırılır ${ }^{47}$ ve Konstantinopolis patriği Photios tarafindan kaleme alınan Myriobiblos (ya da Bibliotheke/Bibliotheca) adlı eserdeki Demetrios'la ilgili metinle paralel ve anonim bir eserdir. ${ }^{48}$ Antik Yunanca eserin eldeki en erken tarihli nüshas1 9. yüzyılda kaleme alınan, bugün İspanya'daki El Escorial-Real Biblioteca'da bulunan

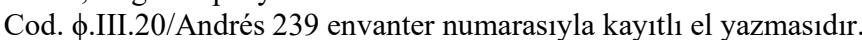
Aziz Demetrios'un vitası folyo 364verso-370verso arasında yer alır. ${ }^{49}$ Passio Prima 876 yilında, Papa II. Adrian (867-872) ve VIII. Ioannes'e (872-882) hizmet eden ve Bibliothekarios (kütüphaneci) unvanı elde eden Anastasios tarafindan Frank kralı II. Charles le chauve (875-877) için Latinceye çevrilir. ${ }^{50}$ Azizin vitasının bir diğer erken tarihli versiyonu, Vatikan Apostolik Kütüphanesi'nde bulunan Vat. gr. 821 envanter numaralı el yazmasinda, folyo 57 verso-61 recto arasındaki bölümde yer alır. Bu versiyon Passio Altera olarak adlandırılmıștır. ${ }^{51}$ Eserde folyo 61verso-84verso arasında Aziz Demetrios'un mucizeleri de bulunmaktadır. ${ }^{52} \mathrm{Bu}$ eserde Demetrios asil bir senatör ve askeri komutan olarak tasvir edilir. ${ }^{53}$ Azizin efsanelerinin bir versiyonunu içeren Vat. gr. 821'in yazarı, olayların gidişatını biraz farklı bir şekilde açıklar ve mevcut anlatılara yeni olaylar ekler. Esere göre; Demetrios senatör bir aileden gelmektedir; orduda iyi bir rütbesi vardır ve sonradan konsül olur. Ancak Demetrios putperestleri Hıristiyanlığa döndürmekle meşguldür. Hagiografinin yazarı, yukarıda söz edilen gladyatör Lyeus'un bir barbar olduğunu ve Selanik'e gelmeden önce Sirmium'da zaten birçok kişiyi öldürdüğünü de bilmektedir. ${ }^{54}$

Aynı eserde Aziz Demetrios'un bir mucizesi ve şehit edilmesiyle ilgili anlatı şu şekildedir:

manoscritte di Spagna: Libri originari o provenienti dall'Italia greca medievale", Rivista di Studi Bizantini e Neoellenici 44, 2007, s. 56-57; A. Džurova, "L'enluminure de l'évangéliaire oncial Beratinus 3 de Tirana. Notes preliminaries", Arte medievale 2, 2008, s. 122; J. Simonet, "Les variantes communes des versions syriaques, arménienne et latine dans le Discours 41 de Grégoire de Nazianze", (ed. A. Schmidt), Studia nazianzenica II, CCSG 73, Turnhout, Brepols, 2010, s. 585-604; A. Džurova, Manuscrits grecs enluminés des Archives nationales de Tirana (VIe-XIVe siècles), Études Choisies 1: Texte, Sofya, 2011, s. 44.

${ }^{50}$ B. Neil, "The Politics of Hagiography in Ninth-Century Rome", Text and Transmission in Medieval Europe, (ed. C. Bishop), Cambridge Scholars Publishing, Newcastle, 2007, s. 71

${ }^{51}$ C. de Bije, "Passio Altera Auctore anonymo a, E Bibliotheca Vaticanæ codice 821", Acta Sanctorum Octobris IV, Brüksel, 1780, s. 90-95.

${ }^{52}$ Vaticanus graecus 821: Bir kısmı 11. yüzyılın ikinci yarısında, 1077 yılında Theodoros isimli kâtip tarafından kaleme alınmıs, derleme bir eserdir. İçinde azizlerin mucizeleri, yaşam öyküleri, çeşitli azizlere yazılmış homiliye'ler ve dini metinler yer alır. Esere ilișkin bkz.; Bije, "Passio Altera", s. 90-95; S. Lucà, "Attività scrittoria e culturale a Rossano: da S. Nilo a S. Bartolomeo da Simeri (secoli X-XII)", Atti del congresso internazionale su S. Nilo di Rossano. 28 settembre- $1^{\circ}$ ottobre 1986, Rossano, Grottaferrata, 1989, s. $25-$ 73; M. B. Foti, "Lo Scriptorium del S.mo Salvatore di Messina", Scritture, Libri e Testi Nelle Aree Provinciali di Bisanzio. Atti del Seminario di Erice (18-25 Settembre 1988), Biblioteca del "Centro per il collegamento degli studi medievali e umanistici nell'Università di Perugia" 5, Centro italiano di studi sull'alto medioevo, Spoleto, 1991, s. 414; P. Canart ve L. Perria, "Les écritures livresques des XI et XII siècles", Paleografia e codicologia greca (Atti del II Colloquio internazionale Berlino-Wolfenbüttel, 17-20 ottobre 1983), Alessandria, 1991, s. 111; A. Jacob, "I più antichi codici greci di Puglia: ovvero un viaggio della paleografia nel paese che non c'è", Studi medievali e

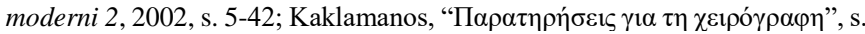
226

${ }^{53}$ Kazhdan ve Ševčenko, "Demetrios of Thessalonike", s. 606.

${ }^{54}$ Delehaye, Les Légendes Gresques, s. 105. 
"Hamamın geçitlerine atılan Demetrios, kendisine saldırmak isteyen bir akrep görür ve onu bir haçla öldürür. Böylece gökten bir melek iner ve Demetrios'un başına bir taç koyar. Lyeus stadyuma getirilirken, Demetrios'un arkadașı Nestor onu tutsak edildiğ $i$ yere bulmaya gider ve gladyatöre karșı vereceği mücadelede dualarıly kendisine destek olmasinı ister. Aziz onu kutsar; zafer kazanıp şehit olacă̆ını tahmin eder. Nestor Isa'yl anar ve Lyeus'u öldürür. Maksimianus Nestor'u büyüye başvurmakla suçlar ve kafasın kestirir. Imparator, Demetrios'un Lyeus'un ölümünden sorumlu olduğu düşünür ve onun mızrakla öldürülmesini emreder." ${ }^{55}$

Aziz Demetrios'a ilişkin yukarıda söz ettiğimiz üç versiyonun sonuncusu Symeon Metaphrastes'e aittir ve 961-964 y1llarında kaleme alınmıştır. ${ }^{56}$ Bugün Athos Dağı'ndaki (Yunanistan) Vatopediou Manastırı'nda Cod. 497 envanter numarasıyla kayıtl bulunan eser Symeon'un metnini içeren en erken tarihli el yazmasıdır Aziz Demetrios'un vitası folyo 272 recto-310recto arasında yer alır. ${ }^{57}$

Demetrios'un mucizelerini içeren yaşam öyküsü 9. yüzy1ldan 17 . yüzyıla kadar 200'den fazla kopya eserde karşımıza çıkmaktadır. Bu eserlerden 136's1 Symeon Metaphrastes'in metninin kopyasıdır. ${ }^{58}$

Aziz Demetrios'un Bizans İmparatorluğu'nda 9. yüzyıldan itibaren yeniden belirgin hale gelen kültü, azizin onuruna yazılan homiliye ve enkomionlar sayesinde kanıtlanabilir. Sözgelimi; İmparator VI. Leon (889-912) Aziz Demetrios onuruna üç homiliye kaleme almıştır. Bu homiliyeler 9. yüzyıl sonu-10. yüzyıl başlarında azizin imparatorluk sarayındaki kültünün önemini de ortaya koyar. VI. Leon ayn zamanda Konstantinopolis'te Aziz Demetrios'a adanan bir kilise inşa ettirmis tek Bizans imparatorudur. 10. yüzyılın başlarında referendarios ${ }^{59}$ Gregorios tarafindan kaleme alınan bir homiliyede VI. Leon'un kilisesinin Büyük Saray kompleksi içinde olduğu aktar1lir. ${ }^{60}$

İmparator VI. Leon'un kendisi Aziz Demetrios'a olan özel bağlılığını açıklamamıştır. Ancak şüphesiz ki kilisenin inşa edildiği dönemdeki resmî tutumunu yansıtan bir kaynaktan, bu bağll1ı̆̆ın nedeni üzerine çıkarım yapılabilir. Bu kaynak Leon'un ilk eşine ilişkin bir eser olan “Azize Theophano'nun Yaşamı"dır ve Leon vitayı Theophano'nun 895/896'daki ölümünden kısa bir süre sonra yazmıştır. ${ }^{61}$

Vita, Eukhaites başpiskoposu Theodoros Santabarenos tarafindan Leon'a karșı yapılan komplo suçlamasının ardından Theophano'nun, Leon'un babası I. Basileios (867-886) tarafindan kınanması utancını

${ }^{55}$ Delehaye, Les Légendes Gresques, s. 105-106.

${ }^{56}$ C. de Bije, "Passio Tertia S. Demetrii M. Auctore Simeone Metaphraste, E Græco bibliothecæ Chrsitianissimi regis Medicæo exemplari, cum Lipomani et Surii editionibus collato", Acta Sanctorum Octobris IV, Brüksel, 1780, s. 96-104; Vickers, "Sirmium or Thessaloniki", s. 343.

57 Codex Graecus 497: 10. yüzyıla aittir; ancak bir kısmı (folyo 108verso122verso) 11. yüzyılda kaleme alınmıştır. Esere ilişkin bkz.; S. Eustratiades ve A. Vatopédinos, Catalogue of the Greek Manuscripts in the Library of the Monastery of Vatopedi on Mt. Athos, Harvard Theological Studies XI, Cambridge, 1924; A. Ehrhard, Überlieferung und Bestand der hagiographischen und homiletischen Literatur der griechischen Kirche von den Anfängen bis zum Ende des 16. Jahrhunderts, vol. II, Leipzig, 1937, anm. 2 .

${ }^{58}$ Liste halinde incelemek için bkz; Pinakes: Textes et Manuscrits Grecs, "Hagiographica, Demetrius m. Thessalonicae (S.), Passio metaphrastica", https://pinakes.irht.cnrs.fr/notices/oeuvre/15317/, 2016, [Erişim Tarihi: 19.10.2020].

${ }^{59}$ Referendarios ( $\dot{\varepsilon \varepsilon \varphi \varepsilon \rho \varepsilon v \delta \alpha ́ \rho ı \varsigma \varsigma): ~ B i z a n s ~ d e v l e t ~ s i s t e m i n d e ~ s i v i l ~ v e ~ d i n i ~ o l m a k ~}$ üzere iki referendarios vard. Birincisi imparatorun sekreterliğini yürütür; emirlerini magistros'lara iletirdi. İlk olarak imparator Iulianos Paravatis (361363) tarafindan kuruldu. İkincisi Konstantinopolis patriği ile imparatorluk sarayı arasındaki iletișimi sağlayan irtibat memuru gibi görev sürdüren ve aslında diyakoz olarak çalıșan din adamlarıydı. A. Kazhdan ve P. Magdalino, "Referendarios", Oxford Dictionary of Byzantium III, (ed. A. P. Kazhdan), Oxford University Press, Oxford, 1991, s. 1778.

${ }^{60}$ Magdalino, "Saint Demetrios", s. 198. ve zindan cezasını nasıl paylaştı̆ı̆ını anlatmaktadır. Theophano ve Leon, Basileios'a karşı suikast düzenlemekle suçlanıp 3 yıl hapis cezasına çarptırılır. ${ }^{62}$ Theophano ve Leon için Aziz Demetrios'un önemi, azizin bir gece çifte görünmesi olayıyla ilişkilidir. Bu olay şu șekildedir:

"Theophano, Leon'a suçlama karşısında umutsuzluğa kapılmamasını, Tanrı'nın Basileios'un aklını başına getirmesi için dua etmesini söyler. Tanrı, Theophano'nun imanını bir işaret ile ödüllendirir. Çift, akşam duasinı ettikten sonra yatağa girdiğinde, asker klyafetli, sağ elinde mizrak ve solunda kalkan tutan genç bir adam onlara görünür. Theophano ve Leon bu gencin, kendilerini infaz etmeye geldiğini düşünürler ve canlarını bağışlaması için yalvarmak üzere dizlerinin üstüne çökerler. Ama iyi haber getiren kişi olarak barış içinde geldiğini söyleyen genç onlar rahatlatır: "Buraya kendim gelmedim, ama beni Selanik'ten siz getirdiniz", der.”; böylece Tanrı onların dualarını işitmiş ve babalarının gerçeği öğreneceğini ve ölmeden önce onlara haklı itibarlarını geri vereceğini bildirmek için onu (Demetrios'u) göndermiştir. ${ }^{63}$

Aziz Demetrios'un mucizelerine ilişkin koleksiyonlardan ayrı olarak keşiş ve filozof Symeon 10. yüzyılın sonu-11. yüzyılın başlarında azizin onuruna bir enkomion kaleme almıştır. ${ }^{64} \mathrm{Bu}$ eserin edebi dili pek çok Homerik ifade içermektedir. Enkomionun yazarı Selanikli Aziz Genç Phantinos'un vitasında adı geçen keşiş Symeon ile özdeşleștirilir. ${ }^{65}$

12. yüzyılda Selanik'in hagiografik literatürdeki koruyucu azizi hakkında en kapsamlı eser Selanik başpiskoposu Eustathios tarafından yazılmıştır. Miryokefalon Savaşı'ndan (1176) hemen sonra yazılan enkomion Eustathios'un Demetrios için yazdığ metin ile bağlantılıdır. Eser Aziz Demetrios'u "mür salgılayan" bir aziz olarak tanımlayan teolojinin gelișimini kanıtlamanın yanı sıra, edebi dili açısından seküler edebiyattan öğeleri sıkça kullanması ve homiletik edebiyatın ortak alanlarından kurtulmasıyla dikkat çeker. ${ }^{66}$

12. yüzyılın ilk yarısında kaleme alınan Bizans seküler edebiyatındaki hiciv örneklerinden biri olan anonim eser "Timarion"da ${ }^{67}$ Aziz Demetrios için düzenlenen Demetria festivalinden söz edilir. Eser, ana karakterin Selanik'in ünlü patron azizi ve koruyucusu Demetrios onuruna düzenlenen festivale katılmak için Konstantinopolis'ten Selanik'e yaptığı yolculukla

${ }^{61}$ Magdalino, "Saint Demetrios”, s. 198. Bulgar Kilisesi tarafindan, kayıp orijinal Yunanca metinden Orta Bulgar Slavcasına çevrilmiștir. Bu eser günümüzde St. Petersburg'daki Ulusal Halk Kütüphanesi'nde yer alan Nr. 51 envanter numaralı eserdir. Kreinina bu eserin olasılıkla 14. yüzyılda yazılmış bir versiyondan tercüme edildiğini belirtir, bkz.; A. Kreinina, "The Life of Theophano The Empress: The Slavonic Version of An Unknown Byzantine Orijinal", Scrinium 7-8(1), 2011, s. 170.

${ }^{62}$ Kreinina, "Life of Theophano", s. 169-170.

${ }^{63}$ Magdalino, "Saint Demetrios", s. 198-199.

64 Eserin Modern Yunanca çevirisi için bkz.; P

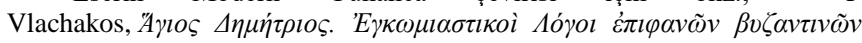

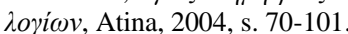

${ }^{65}$ Eser günümüzde Rusya'da, Moskova'daki Ulusal Tarih Müzesi'ndedir, env. no: Sinod. gr. 478/Vlad. 136. Selanikli Aziz Genç Phantinos'un vita'sı folyo 272 recto-286recto arasinda yer alır.

66 S. A. Paschalidis, "The Hagiography of The Eleventh and Twelfth Centuries", The Ashgate Research Companion to Byzantine Hagiography I: Periods and Places, (ed. S. Efthymiadis), Ashgate, Farnham, Burlington, 2011, s. 155-156.

${ }^{67}$ Timarion'a ilisskin bkz.; B. Baldwin (İngilizce’ye çev.), Timarion, Wayne State University Press, Detroit, 1984; A. Kazhdan, "Timarion", Oxford Dictionary of Byzantium III, (ed. A. P. Kazhdan), Oxford University Press, Oxford, 1991, s. 2085; A. Kaldellis, "Hellenic Afterworlds: The Timarion", Hellenism In Byzantium The Transformationsof Greek Identity and The Reception of The Classical Tradition, Cambridge University Press, New York, 2007, s. 276-282. 
başlar. ${ }^{68}$ Timarion, yaptığ 1 hac ziyaretinde, dünyanın dört bir yanından Demetria fuarında ticaret yapmak için kente gelen tüccarları görür. ${ }^{69}$ Fuarı daha iyi görmek için bir tepeye tırmanır ve fuarda iki paralel çizgi halinde kurulan satış pavyonlarının düzeni adeta bir kırkayak izlenimi uyandırmaktadır. Fuarda tüccarlara çok sayıda hayvan eşlik etmektedir. Timarion daha sonra kiliseye gider ve burada bir başpiskopos tarafindan yönetilen iki koronun katıldığ 1 ve bir meşaleyle aydınlatılmış gece ibadetine denk gelir. Şafak vaktinde kiliseye yerel bir vali gelir. Vali, başpiskoposa töreni başlatmasın söyler. Burada keşiş ve rahibelerden oluşan iki koro yer almaktadır. Daha sonra tören sona erer ve Timarion kalabalıkla birlikte oradan ayrılarak, kaldığı yere geri döner. ${ }^{70}$ Günümüzde Aziz Demetrios anma günü Ortodoks Kilisesinde 26 Ekim'de kutlanmaktadır.

Aziz Demetrios'a ilişkin bir başka metin Konstantinopolis’teki önemli kutsal kalıntılarla ilgili hagiografik metinler bağlamında önem arz eder. Bu metin Konstantinopolis'teki Pantokrator Manastırı'nın keşişi Nikasios tarafindan, Aziz Demetrios'un röliklerinin 1149 Mart'ında sarılmış olduğu kutsal kefenin Selanik'ten Konstantinopolis'e taşınması vesilesiyle yazılan kısa bir metindir. ${ }^{71}$

Aziz Demetrios'un mucizeleri popülerlik kazanmaya devam ederken; çoğunlukla kanonik çalışmaları ve hagiografi metinleri ile tanınan 12. yüzyılın başlarında Selanik başpiskoposu Niketas ve 13. yüzyılın ortalarında Ioannes Stavratikos tarafindan azizin mucizelerinin iki versiyonu daha ortaya konur.

Niketas esasen Aziz Demetrios'un mucizelerinin iki koleksiyonundan aldığı, ayrıca Passio Altera olarak bilinen azizin mucizeleriyle ilişkili diğer eserden iki mucize alarak ve ilgili anlatılardan özgürce yararlanarak, 16 mucizeden oluşan bir koleksiyon derlemiştir. $^{72}$

Niketas'ın kaleme aldığı metnin 12 . yüzyıla ve 13 . yüzyıla ait iki farklı versiyonu vardır. 12. yüzyıla ait nüsha Sina'daki (Mısır) Katherina Manastırı'nda Cod. gr. 516 envanter numaralı el yazmasidır ve Aziz Demetrios'un mucizeleri folyo 173recto211 recto arasında yer alır. ${ }^{73} 1260$ 'larda yazılan diğer kopya Oxford'daki Bodleian Kütüphanesi'nde yer alan Barocci 131

\footnotetext{
${ }^{68}$ Kaldellis, "Hellenic Afterworlds", s. 277.
}

${ }_{69}$ Timarion'da fuara Boiotia ve Peloponnessos kentlerinden getirilen kumaşlardan (muhtemelen ipek) söz edilmektedir. Fuara Venedikli İtalyan tüccarların da katıldığı tahmin edilmektedir, bkz.; D. Jacoby, "Venetian Commercial Expansion in The Eastern Mediterranean", Byzantine Trade 4th12th Centuries The Archaeology of Local, Regional and International Exchange, (Papers of the 38th Spring Symposium of Byzantine Studies, St John's College, University of Oxford, March 2004), (ed. M. M. Mango), Ashgate, Surrey, Burlington, 2009, s. 379-380.

${ }^{70}$ B. MacDougall, "The Festival of St. Demetrios, The Timarion, and The Aithiopika", Byzantine and Modern Greek Studies 40(1), 2016, s. 136-150.

${ }^{71}$ Paschalidis, "The Hagiography", s. 158.

${ }^{72}$ Paschalidis, "The Hagiography", s. 147.

${ }^{73}$ Esere iliskin bkz.; K. Krumbacher, Geschichte der Byzantinischen Litteratur von Justinian bis zum Ende des Oströmischen Reiches (527-1453), Münih, 1897, 90/no.1; Kaklamanos, "П Sarris, Classification of finishing tools in Greek bookbinding: establishing links from the Library of St Catherine's Monastery, Sinai, Egypt, cilt 1, Basılmamıs Doktora Tezi, University of the Arts, Londra, 2010, s. 132.

${ }^{74}$ El yazmasına ilişkin bkz.; D. Bianconi, "Libri e mani. Sulla formazione di alcune miscellanee dell'età dei Paleologi", Il codice miscellaneo. Tipologie e funzioni. Atti del Convegno internazionale (Cassino, 14-17 maggio 2003), Segno e testo 2, 2004, s. 332-333; D. Marcotte, "Une carte inédite dans les scholies aux Halieutiques d'Oppien. Contribution à l'histoire de la géographie sous les premiers paléologues", Revue des études grecques 123, 2010, s. 649650,653 ; R. C. Sánchez," "Historia del texto del Comentario anónimo al Tetrabiblos de Tolomeo", MHNH Revista internacional de investigación sobre Magia y Astrología antiguas 13, 2013, s. 183-184; F. Acerbi ve A. Gioffreda, "Manoscritti Scientifici della prima età Paleologa in Scrittura Arcaizzante", Scripta 12, 2019, s. 16, 24, 41-42. envanter numaralı eserdir ve Demetrios'a ilişkin bölüm folyo 523recto-536verso arasinda yer alır. ${ }^{74}$

Selanik Kilisesi'nin khartopylaks ${ }^{75}$ Ioannes Stavratikos'un kaleme aldığı Demetrios'un mucizelerinin ve yaşam öyküsünün derlendiği üç yazma vardır. Bu eserlerden biri Floransa'da Biblioteca Nazionale Centrale'de bulunmaktadır ve Con. Sopp. B.I.1214 envanter numarasıyla kayıtlıdır. Eser 14. yüzyıla tarihlenir. ${ }^{76}$ Diğer eser 14. yüzyıl ortalarına aittir ve Athos'taki İveron Manastırı'nda Cod. gr. 677 envanter numarasiyla kayıtlıdır. ${ }^{77}$ Son yazma, Yunanistan'da, Zavorda'daki Aziz Nikanoros Manastırı koleksiyonundaki Cod. gr. 147 envanter numaralı eserdir. ${ }^{78}$

Bizans'ın geç dönem hagiografik yazını içinde Demetrios'a ilişkin bir metin 14. yüzy1l ortalarında Nikephoros Gregoras tarafindan yazılan enkomiondur. ${ }^{79}$ Aziz Demetrios'a adanan enkomion, günümüzde Kudüs'teki Patrikhane Kütüphanesi'nde Monê Abraham/Cod. 51 envanter numarasıyla kayıtlı eser içinde, folyo 68verso-78recto arasında yer alır. Yine 14. yüzyılın ikinci yarısında Aziz Demetrios onuruna yazılan bir başka enkomion Konstantinos Armenopoulos tarafından kaleme alınmıştır. Bu eser bugün Atina'daki Ulusal Kütüphane'nin koleksiyonundadır ve Cod. 2118 envanter numarasıyla kayıtlıdır. ${ }^{80}$

\section{Aziz Demetrios ve Mür Yağı İlişkisi}

Aziz Demetrios'un kültü kilisenin içinde olduğu kabul edilen mezarında bulunan kutsal kemiklerinin, 11. yüzyıldan itibaren "mür

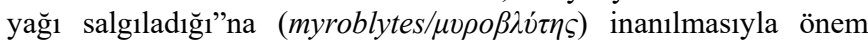
kazanır (G.5). Dolayısıyla "büyük din şehidi" (megalo martyros) olarak anılan Demetrios'un unvanına "mür yağı salgılayan" anlamına gelen bir yenisi eklenir: myroblytos. ${ }^{81}$ Mür yağ 1 azizin mezarının yakınındaki havuza bir dizi boru yoluyla akıtılmıştır. ${ }^{82}$

14. yüzyılda Trabzon başpiskoposu Ioannes Lazaropoulos (13641367) tarafindan bir araya getirilen Trabzonlu Aziz Evgenios'un mucizelerine ilişkin eserinde söz edilen 9. yüzyılın sonu veya 10 . yüzyılın başındaki bazı olaylara bakılırsa, Aziz Demetrios'un mür ile ilişkisinin 11. yüzyıldan daha erken bir dönemde ortaya çıkmış olduğu anlaşı1ır. ${ }^{83}$
${ }^{75}$ Khartopylaks: Bazı manastırlarda, manastır kayıtlarının korunması ve geçici belgelerin kaydını tutmakla görevli keşişlere verilen unvan. Ayrıntılar hakkında bkz.; R. J. Macrides, "Chartopylax", The Oxford Dictionary of Byzantium I, (ed. A. P. Kazhdan), Oxford University Press, Oxford, 1991, s. 416.

${ }^{76}$ Esere dair bkz.; W. Jaeger, J. Cavarnos, V. W. Callahan, Gregorii Nysseni Opera ascetica, Gregorii Nysseni Opera VIII.1, Brill, Leiden, 1952, s. 351352; P. Chiesa, Le versioni latine della Passio sanctae Febroniae-Storia, metodo, modelli di due traduzioni agiografiche altomedievali, Spoleto, 1990, s. 340; C. Rapp, "Figures of Female Sanctity: Byzantine Edifying Manuscripts and Their Audience", Dumbarton Oaks Papers 51, 1996, s. 317, 334-342; E. Mineva, The Byzantine Hagiographic and Hymnographic Texts on St Parasceve of Epibtae. I, The Byzantine vita of St Parasceve of Epibatae or the vita by "Vasilikos the Deacon", Publishing Center "Boyan Penev", Institute for Literature, Bulgarian Academy of Sciences, Sofia, 2017, s. 58-67.

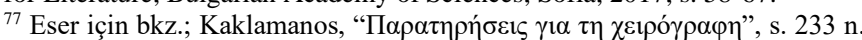
77.

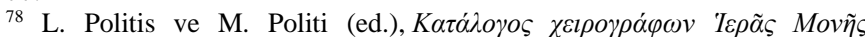

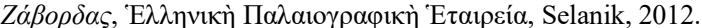

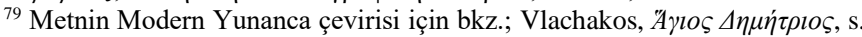
70-101.

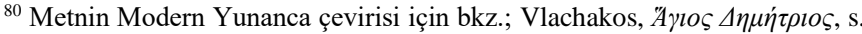
380-435.

${ }^{81}$ Kazhdan ve Ševčenko, "Demetrios of Thessalonike", s. 605.

82 J. C. Skedros, "Shrines, Festivals, and the <Undistinguished Mob>", $A$ People's History of Christianity 3: Byzantine Christianity, (ed. D. Krueger), Fortress Press, Minneapolis, 2010, s. 94.

${ }^{83}$ Ayrıntılar için bkz.; Bakirtzis, "Pilgrimage to Thessalonike", s. $176 \mathrm{vd}$. Iohannes Lazaropoulos'un eserinin tek kopyası Athos'taki Dionysiou Manastırı'nda yer alan 1445 tarihli Cod. 154 envanter numaralı eserdir; R. S. 


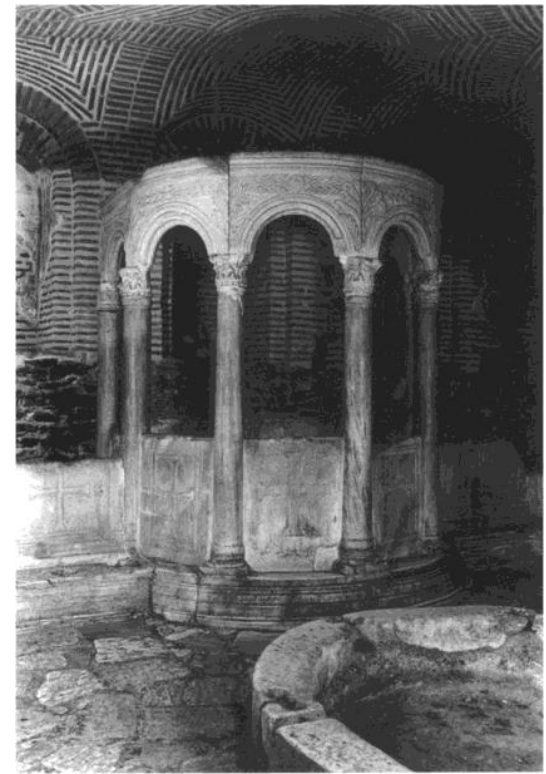

G.5. Aziz Demetrios Kilisesi'ndeki krypta bölümü ve kutsal mür yăğ kaynağı kabul edilen havuz, Selanik, Yunanistan (Bakirtzis’ten).

Ioannes Skylitzes'in "Synopsis"inde anlattığı bir olay, Aziz Demetrios'un 11. yüzyılın ilk yarısında Selanik'teki kültünün ve mür yağıyla ilişkisinin önemini ortaya koymaktadır:

"Bir gün bölge halkı büyük martyr Demetrios'un mezarına gitti ve kutsal mezardan akan mür ile kendilerini mesh etmek için tüm gece boyunca şefaat dilediler. Sonra bir anlaşmayla kapıları açtılar ve Bulgarların karşısına çıktılar, cesur yürekler (megathymoi) birliği Selanik'in adamlarıyla birlikteydi. Dışarı çıktılar, saldırının beklenmedik olması nedeniyle Bulgarları kargaşaya sürükleyerek onlarl geri püskürttüler. Bulgarlar Roma ordusuna liderlik eden ve ona yol gösteren din şehidine uzatmal ve gözü pek bir direniş göstermeye en ufak bir gönüllülük içinde değillerdi. Onlar Roma birliklerine liderlik eden atlı bir genç ve düşmanları yakan bir ateş görmüşlerdi; bu, esir alınan bazı Bulgarlar tarafindan yeminlerle tasdik edilmiştir". ${ }^{84}$

Synopsis'teki bu metin, Selanik halkının, Bulgarlarla savaşa girmeden önce, kendilerini mür yağı ile ovduklarını belirtmesi ve mürün kaynağı olarak azizin "sözde" mezarını işaret etmesi bakımından oldukça önemlidir. Üstelik Bizans ordusuna Demetrios'un önderlik ettiğine inanıldığını vurgulamasının yanı sıra, buna Bulgarlar tarafindan şahit olunduğunu ve yeminlerle onaylandığını da dile getirmesi ilginçtir. Skylitzes'in bahsettiği olay 1040 yılı civarlarında, imparator IV. Mikhail (Paflagonyall) döneminde (1034-1041) gerçekleşmiştir. ${ }^{85}$

13. yüzyılda, Konstantinopolis'teki Latin istilası sırasında, Aziz Demetrios'un kültü yeniden belirir. 1220'lerde iki isim, I. Theodoros Komnenos Dukas ve III. Ioannes (Vatatzes) Bizans'in imparatoru ilan edilir. 1227'de Selanik'teki Latin istilasını bertaraf eden I. Theodoros, kentte, Ohri başpiskoposu Demetrios Khomatenos tarafından taçlandırılır. III. Ioannes ise adı bilinmeyen bir Konstantinopolis patriğinin elinden taç giymiştir.

Stefec, "Aspekte Griechischer Buchproduktion in der Schwarzmeerregion", Scripta 7, 2014, s. 214.

${ }^{84}$ J. Skylitzes, A Synopsis of Byzantine History 811-1057, (İngilizceye çev. J.

Wortley), Cambridge University Press, Cambridge, 2010, s. 388.

85 Bölüm 19:27'nin metni șu cümleyle başlamaktadır: "Eylül ayında, indiksiyonun 9. yıl1, Anno Mundi 6459 (1040)...”; Skylitzes, Synopsis, s. 387.
Bu dönemde İznik (Nikaia) patriği Germanos ile Demetrios Khomatenos arasındaki yazışmalar Aziz Demetrios'un dönemin kiliseye dayalı en önemli tartışma konusu olduğunu gösterir. Söz konusu olan sorun, Theodoros yönetimindeki Bizanslıların siyasi ve dini bağımsızlığıydı ve bu bağımsızlığı savunmak için kullanılan sembol, Aziz Demetrios'un mür yağıydı. ${ }^{86}$

İznik patriği Germanos, her yıl Patrikhane'de Kutsal Hafta boyunca yapılan ve kendi yetkisi altındaki kiliselere vaftizde kullanılmak üzere dağıtılan kutsal yağ olan mürün üretiminde tekelciliğin hüküm sürdüğünü iddia etti. Mür yağı ayrıca taç giyme töreninde imparatorları meshetmek için kullanılmaktaydı. $\mathrm{Bu}$ nedenle üretiminin patrikliğe ait bir tekel olması gerekiyordu. Germanos, Demetrios Khomatenos'a Selanik'te I. Theodoros'u meshetmek için kullanılan mürün kaynağını bilmek istediğini bildirdi; alaycı bir tavırla Demetrios'un adaşı aziz gibi bir myroblytes olup olmadığını sordu. Khomatenos, Germanos'a cevabında üretimin patrikliğe ait olduğunu herhangi bir piskoposun mür üretimini yapabileceğini belirten 5. yüzyılın kanon yasasını hatırlattı. ${ }^{87}$

Ioannes Stavratikos'un bir eserinde Aziz Demetrios'un mür yağına ilişkin anlatısı şu şekildedir: "Erkekler, kadınlar ve çocuklar mür yağını elleriyle çıkarıyor, gözlerini, ağızlarını, kulaklarını, bağırlartyla ve tüm vücutlartyla birlikte mesh ediyor... Her yaştan ve milletten sonsuz sayıda insan din şehidinin mürüyle mesh ediliyor; özellikle kadınlar durmaksızın gözlerini ve bağılarını, göğüslerini ve kollarını mesh ediyor." $" 88 \mathrm{Bu}$ metin, 13. yüzy1lın ortalarında azizin mür yağı ile ilişkili kültünün popülerliğini ortaya koyar.

\section{Aziz Demetrios'un Bizans Dönemine Ait Tasvirlerinden Örnekler}

Aziz Demetrios Bizans tasvirlerinde iki temel tipte karşımıza çıkar: sivil ve asker olarak. Tüm tasvirlerde aziz, geleneksel olarak, kutsallığ vurgulanmak üzere hale ile betimlenir. Sivil Demetrios eğer tam boy betimlendiyse, uzun bir khlamys içinde Romalı bir senatör gibidir. Asker olarak Demetrios bazen at üzerinde, bazen ayakta, kimi örneklerde ise tahtta otururken, elinde kılıç ya da mızrakla betimlenmiştir. Kılıç çoğunlukla azizin dizleri üzerinde durur. Kılıç ya da mızrağa bazen de kalkan eşlik eder.

Lemerle; Aziz Demetrios'un ikonografisindeki aziz veya sivil olarak betimlenmesindeki farklılığın Selanik başpiskoposu Ioannes'in kaleme aldığı "Mucizeler" (Miraculo) eseriyle ilişkili olarak; Mucizeler'de anlatılan Selanik'e karşı gerçekleşen Eylül 586'daki Avar-Slav akınları sırasında Demetrios'un ortaya çıkarak barbarlara görünmesi ve böylece onun asker kimliğine bürünmesi doğrultusunda değişime uğradığını vurgulamaktadır. ${ }^{89}$

Aziz Demetrios'un erken tasvirlerine, Selanik'te onuruna inşa edilen kiliseden günümüze ulaşan mozaiklerde rastlanır. Kilisenin mozaikleri iki farklı evrede yapılmıştır. Birinci evre mozaikleri yapının ilk inşa edildiği dönemle çağdaştır. Yapı, "Aziz Demetrios'un Mucizeleri”nde de söz edildiği üzere 7. yüzyılda yangın geçirmiş; yapının ikinci evresini teşkil eden bu dönemde mozaiklerin bir kısmı yenilenmiştir. ${ }^{90}$

Kilisenin kuzey iç nefinde yer alan mozaikler dışında, diğer mozaikler, güney ve kuzey iç neflerin batı duvarında bulunan pano yüzeylerindedir. Lasareff'e göre; bu mozaikler 500 yılı civarına aittir ve kuzey iç nefteki arkad mozaiklerinden bir yüzyıl önce yapılmışlardır. R. Cormack ise bir veya daha fazla yerel atölye 
tarafından üretilen ve 5. yüzyılın sonlarına ait bir tarihin dikkate alınması gerektiği bir mozaik grubunun varlığını dile getirir; ki bunlar ilk evre mozaikleridir. ${ }^{91}$

Kilisenin 1917 yangını öncesindeki mozaiklerinde Aziz Demetrios'un tasvirlerinin bulunduğunu, 1909 yılında İngiltere'deki Byzantine Research and Publication Fund ve IV. Bute Markizi John'un bağışılyla desteklenen, Royal Institute of British Architects and Soane Medallist öğrencisi W. S. George (1962†) tarafından 18 varak halinde yapılan suluboya kopyalardan öğrenmekteyiz (G.6-7ac). ${ }^{92}$

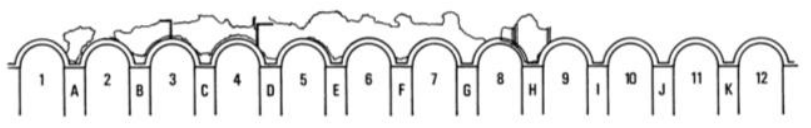

G.6. Aziz Demetrios Kilisesi'nin 1917 yangını öncesinde mozaiklerinin konumunu gösteren diyagram (Cormack'ten).
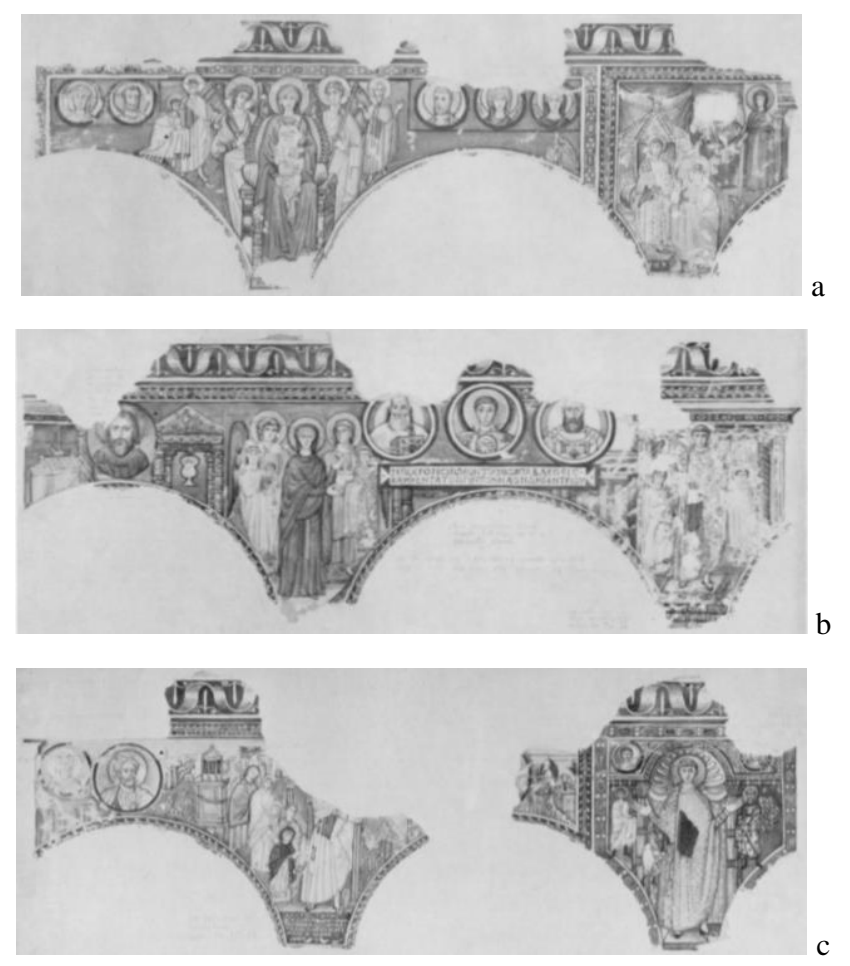

G.7.Aziz Demetrios Kilisesi'nin 1917 yangını öncesinde mozaiklerin suluboya kopyası, Warburg Institute, University of London, Londra [Diyagram üzerindeki yerlerine göre, a.3C-4D / b.5E-6F / c.7G-8H], (Cormack'ten).

Aziz Demetrios, kilisenin tüm mozaiklerinde sivil bir figür olarak temsil edilmiştir ve beyaz khlamys içindedir. Tasvirlerdeki ortak nokta Aziz Demetrios'un başının çevresinde altın yaldız zeminli bir haleyle, tam boy ve cepheden, bir podest üstünde betimlenişidir. Fiziksel özellikleri açısından, sarı tonundaki kısa saçları, oval biçimli genç yüzü ve donuk bakışları ile tüm mozaiklerde aynı özellikleri sergiler (G.8a-e). Ancak kuzey doğu payenin batı yüzüne işlenmiş mozaikte iki çocuğun arasında betimlenen Aziz Demetrios'un saçları küt ve dalgalıdır (G.8e). Bu tiplemeyle Aziz Demetrios kilisede bir başka mozaik panoda betimlenen Aziz Sergios'u andırmaktadır.
W. E. Kleinbauer Aziz Demetrios Kilisesi'ndeki figür üslubunu Selanik'teki Aziz Georgios Rotondu'nun mozaiklerinde görülen üslupla karşılaştırır:

“Rotondda olduğu gibi yüz büyük boyutlu ve hipnotik gözleri vurgulayacak şekilde oluşturulmuştur. Gözlerin ve göz çukurlarının, burnun ve ağzın işlenişi dikkat çekici bir biçimde Rotonddaki bazı figürlerin yüzünü andırır. Gözlerde gözbebekleri tek bir siyah tesserae ile gösterilir; ağız küçüktür ve tek stra tessarea ile işlenmiştir. Rotondda olduğu gibi burun, ağız ve kulakları sınırlamak için kırmızı tessarea 'lar kullanılmıştır. ${ }^{93}$
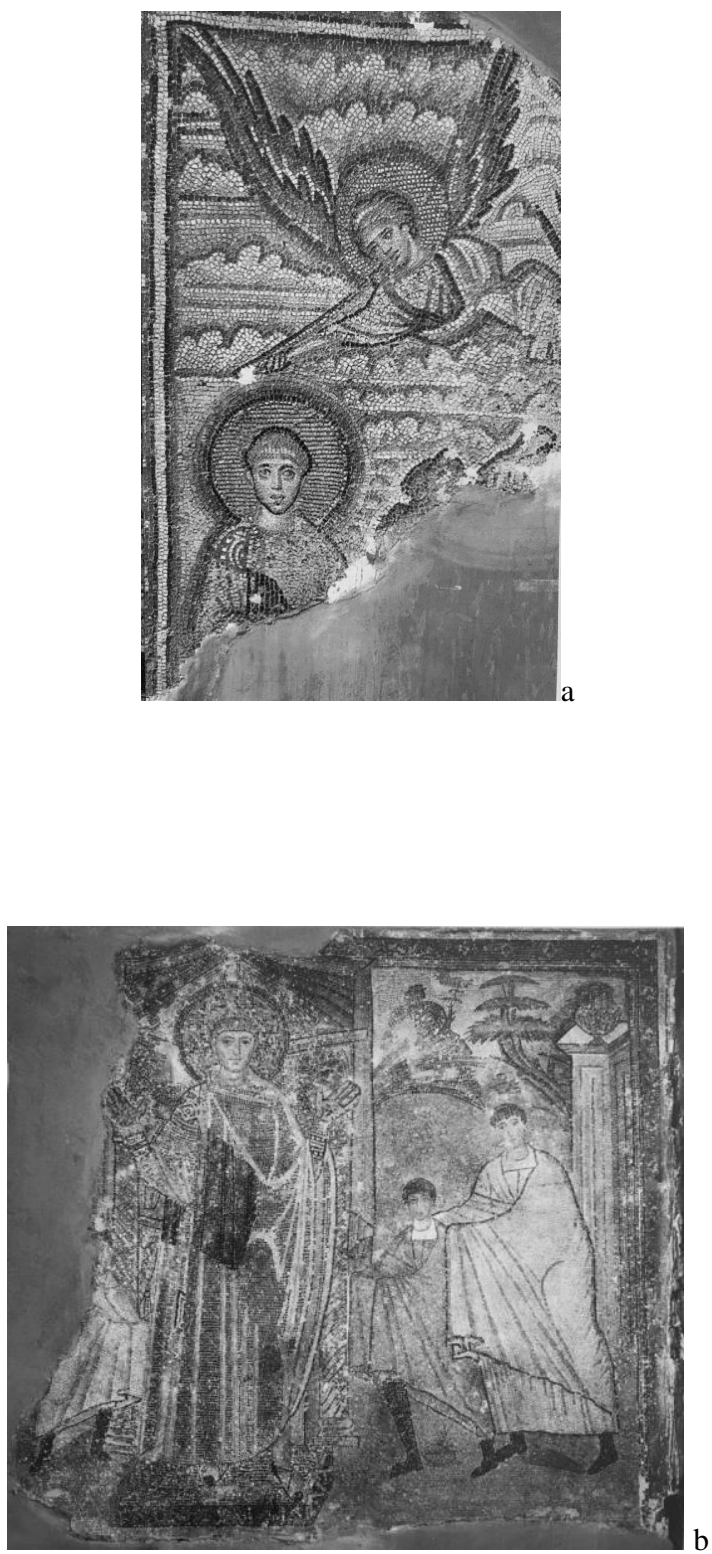

${ }^{91}$ Cormack, "Mosaic Decoration”, s. 48, 49.

${ }^{93}$ Kleinbauer, "Dating of S. Demetrius", s. 43.

92 Varaklar bir süre British Museum'da korunduktan sonra 1960 yılında University of London bünyesindeki Warburg Institute'a götürülmüştür, Cormack, "Mosaic Decoration", s. 19-20. 

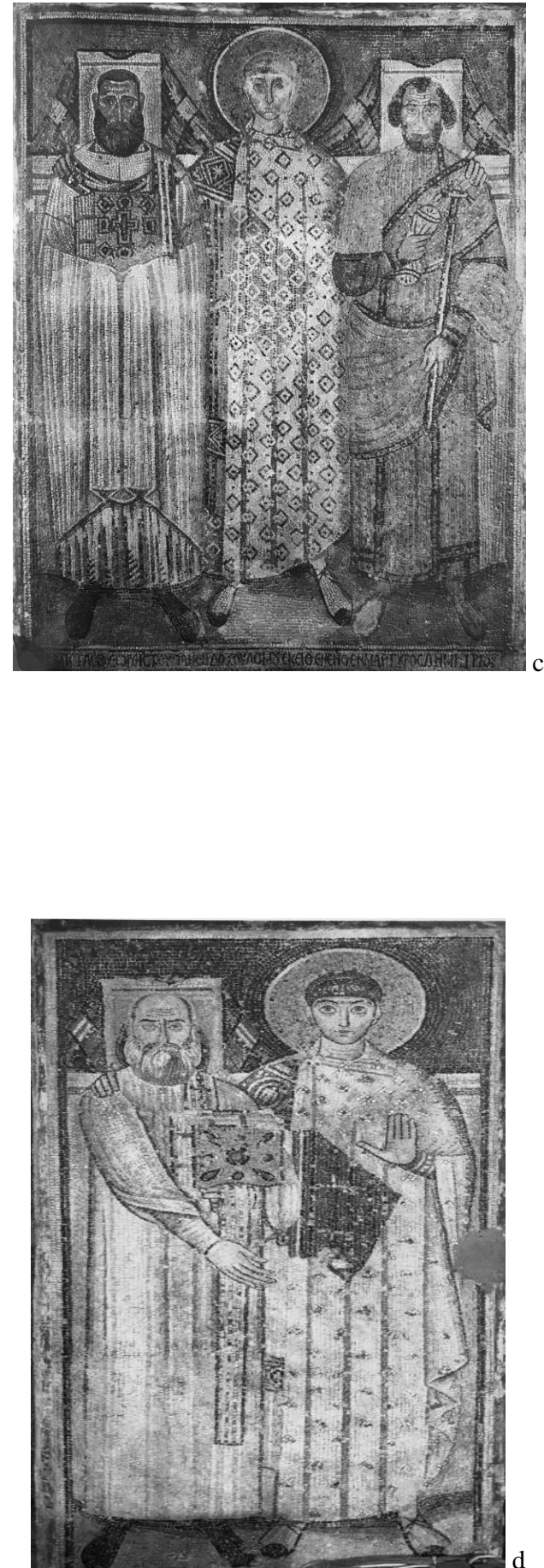

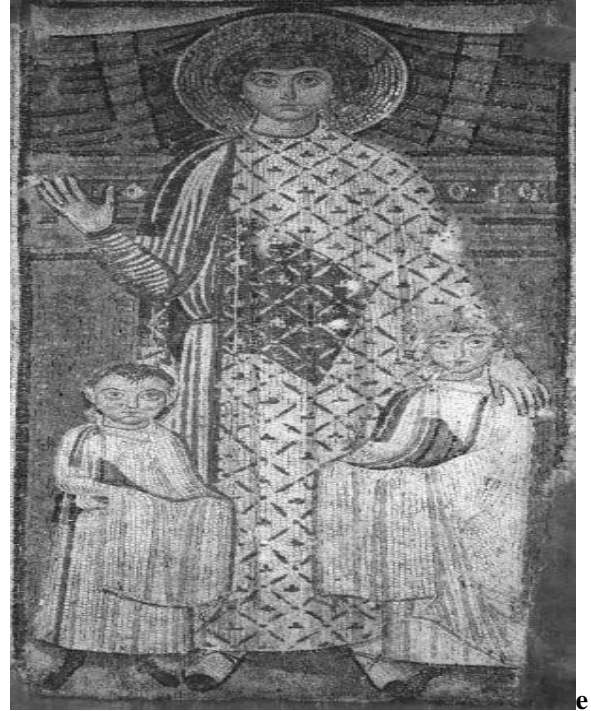

G.8. Aziz Demetrios Kilisesi mozaikleri, [a.Aziz Demetrios ve melek, kuzey iç nef batı duvarı / b.Bir çocuğun Aziz Demetrios'a teslim edilmesi, güney batı payenin doğu yüzü / c.Selanik valisi, Aziz Demetrios ve Selanik patriği, güney doğu payenin kuzey yüzü / d.Aziz Demetrios ve bir diyakoz, güney doğu payenin doğu yüzü / e.Aziz Demetrios ve iki çocuk, kuzey doğu payenin bat1 yüzü], Selanik, Yunanistan (Koukourtidou-Nikolaidou ve Tourta'dan).

Bizans dönemine ait mühürlerde, Aziz Demetrios tam boy, at üzerinde ve büst halinde olmak üzere üç farklı tipte karşımıza çıkar. Aziz Demetrios'un mühürlerdeki tasvirlerine en erken 6.-7. yüzyıllarda rastlanır. Dumbarton Oaks Koleksiyonu'nda yer alan bu döneme ait bir kurşun mührün (env. no.: BZS.1958.106.2760) ön yüzünde beliren Aziz Demetrios ayakta durur, sağ elinde uzun bir haç taşır, sol elinde ise mızrak ya da kılıç vardır. Haç, azizin martyr oluşunun bir sembolüdür. Azizin adı mührün ön yüzüne işlenmiştir ve yazıt şu şekilde okunur: $\mathrm{O}|\Delta| \mathrm{H}|\mathrm{M}| \mathrm{H}-\mathrm{T}|\mathrm{P}| \mathrm{IO} \mid \Sigma \quad(\dot{o}$

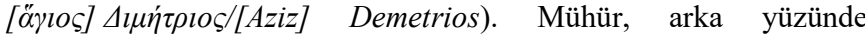
monogramı işlenen -anonim- Hadrianos'a ('A $\delta \rho \alpha v o \tilde{)})$ aittir. $^{94}$

Aynı koleksiyondaki 8. yüzyıla bir başka mühürde (env. no.: BZS.1951.31.5.1307) Aziz Demetrios'un büst olarak tasvir edildiği dikkati çeker. Figürün elinde martyr haçı vardır; iki yanına siglası işlenmiştir: $\mathrm{OA} \mid \Delta \mathrm{I}$ ( $\dot{o} \ddot{\alpha}[\gamma l o \varsigma] \Delta \imath[\mu \eta \dot{\tau} \tau \rho \imath o \varsigma] / A z i z$ Demetrios). Mühür, arka yüzündeki yazıtta okunduğu üzere, Selanik başpiskoposu Petros'a (688/689) aittir ve haç biçiminde işlenmiş monogramda A-

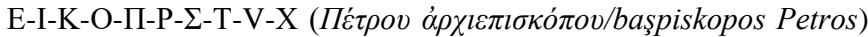
ve etrafinda $\Theta \mathrm{E} \Sigma \Sigma \mathrm{A} \Lambda \mathrm{ONIKH} \Sigma(\Theta \varepsilon \sigma \sigma \alpha \lambda$ ovík $\varsigma /$ Selanik $)$ yazıtı okunur. ${ }^{95}$

11. yüzyıldan itibaren Aziz Demetrios'un mühürlerde sıklıkla betimlenmiş olduğu eldeki örneklerden anlaş1lır. 10. yüzyıl mühürlerinde figür genellikle büst halinde gösterilirken; 11. yüzyılda tam boy olarak betimlendiği örnekler artmaya başlar. Dumbarton Oaks'ta yer alan, 10./11. yüzyıla ait bir örnekte (env. no.: BZS.1947.2.405) Aziz Demetrios büst olarak karşımıza çıkar. Figürün sağ elinde mızrak, sol elinde kalkan vardır. Figür puantiyelerden oluşan bir bordürle çevrelenmiştir. Ön yüzdeki yazıt şu şekildedir: $\Theta|\Delta| \mathrm{H}|\mathrm{M},-..| \mathrm{I} \mid \mathrm{O} \quad(\dot{o} \quad \ddot{\alpha}[\gamma l o \sigma] \quad \Delta \eta \mu(\dot{\eta})[\tau \rho] l o(\sigma) / A z i z$
${ }^{94}$ Görsel için bkz.; Dumbarton Oaks Resources Byzantine Seals, "Adrian (sixth/seventh century)", https://www.doaks.org/resources/seals/byzantineseals/BZS.1958.106.2760/view, Trustees for Harvard University, Washington D.C., 2020 [Erişim Tarihi: 25.10.2020].
95 Görsel için bkz.; Dumbarton Oaks Resources Byzantine Seals, "Peter arcbishop of Thessalonica (eighth century)", https://www.doaks. org/resources/seals/byzantine-seals/BZS.1951.31.5.1307/view, Trustees for Harvard University, Washington D.C., 2020 [Erişim Tarihi: 25.10.2020]. 


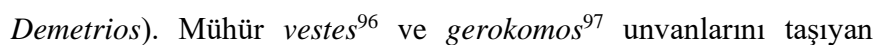
Mikhail adlı birine aittir. ${ }^{98}$

Vestes ve gerokomos Mikhail'e ait aynı koleksiyonda iki kurşun mühür örneği daha vardır ve bu mühürlerde yine büst halinde Aziz Demetrios karşımıza çıkar (env. no.: BZS.1955.1.254799 ve BZS.1955.1.2548 $\left.{ }^{100}\right)$.

Aynı koleksiyondaki 10.-11. yüzyıla ait komes tou Arithmos ${ }^{101}$ Leon'un mührünün (env. no.: BZS.1958.106.3423) ön yüzünde Aziz Demetrios büst halindedir; sağ eliyle takdis işareti yaparken, sol elinde bir kodeks vardır. Figür inci dizisinden oluşan bir bordür içine alınmıştır. Figürün iki yanında $\quad \odot|\Delta| \mathrm{H}|-\mathrm{M}| \mathrm{T} \mid \mathrm{P} \quad(\dot{o} \quad \ddot{\alpha}[\gamma l o \varsigma]$ $\Delta \eta \mu \eta \dot{\tau} \rho\left[\right.$ [os]/Aziz Demetrios) yazit1 okunur. ${ }^{102}$

12. yüzyıla ait, aynı koleksiyonda yer alan, bir kurşun mühür örneğinde (env. no.: BZS.1951.31.5.2611) Aziz Demetrios bu kez at üzerindedir; sağ elinde bir mızrak tutarken betimlenmiștir. Figürün iki yanında bulunan yazıtta $\mathrm{O}|. ..| \Delta \mathrm{H}-\mathrm{MHTPI} \mid \mathrm{O} \Sigma$ (ó $[\ddot{\alpha} \gamma l o \sigma]$ $\Delta \eta \mu \dot{\tau} \tau \rho ı$ /Aziz Demetrios) yazmaktadır. ${ }^{103}$

Dumbarton Oaks Koleksiyonu'nda bulunan, Selanik başpiskoposu Ioannes'e ait, yaklaşık 1198 tarihli kurşun mühürde (env. no.: BZS.1958.106.10) Aziz Demetrios tam boy, ayakta, sağ elinde mızrak ve sol elinde kalkan ile betimlenmiştir. Mühürde, Demetrios'un yer aldığı yüzde iki yazıt bulunur. İlk yazıt Aziz Demetrios'u tanımlar: $\mathrm{OA}|\Delta| \mathrm{H}|\mathrm{M}| \mathrm{H}-\mathrm{T}|\mathrm{PI}| \mathrm{O} \mid \Sigma$ (ó $\ddot{\alpha}[\gamma ı o \varsigma] \Delta \eta \mu \eta ́ \tau \rho ı \varsigma)$ İkinci yazıt bir bordür içinde figürün etrafını kuşatır: A... $\Delta$ HMHTPIE

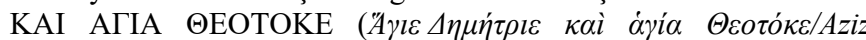
Demetrios ve Tanrl Anasi). ${ }^{104}$

Aziz Demetrios Bizans sikkelerinde en sik yer alan asker azizlerden biri olmuştur. Demetrios sikkelerde tek başına tam boy, yarım boy, büst olarak, tahtta otururken betimlendiği gibi, kimi örneklerde imparator ya da despot ile birlikte temsil edilmiştir. Sikkelerde Aziz Demetrios'un başının çevresinde daima hale yer alır; figür asker kostümü içindedir, bir kalkan ve bir kılıç ya da mızrak taşır; azizin kimliği sikke kitabesi yardımıyla tanımlanır. Asker aziz olarak Demetrios, kısa khlamys üzerine klivanion (zırh) giyer ve kimi zaman lacerna (pelerin) kuşanmıştır.

Aziz Demetrios, Konstantinopolis, Trabzon (Trapezounta) ve Selanik (Thessaloniki) sikkelerinde karşımıza çıkar. 11. yüzyılın büyük bir kısmında sikkelerin üretim ve imparatorluk için tedariğinde, baskın olan Konstantinopolis olsa da; 11. yüzyılın ikinci yarısından itibaren özellikle bronz sikke basımında biri Konstantinopolis, diğeri Selanik merkezli olmak üzere iki darphane ön plana çıar. Selanik'te bir vilâyet darphanesi $1040 / 1041$ 'de ve daha sonra III. Nikephoros döneminde (1078-1081) faaliyet göstermiştir.

\footnotetext{
${ }^{96}$ Vestes: 11. yüzyılda seçkin generallerin taşıdığı bir unvan iken yüzyılın sonlarına doğru daha düşük rütbeli memurların kullandığı bir unvan haline gelmiştir, bkz.; A. Kazhdan, "Vestes", The Oxford Dictionary of Byzantium III, (ed. A. P. Kazhdan), Oxford University Press, Oxford, 1991, s. 2162-2163. 97 Gerokomos: Gerokomeion denilen yaşlilar evinin yöneticisi; bkz. A Kazhdan, "Gerokomos", The Oxford Dictionary of Byzantium II, (ed. A. P. Kazhdan), Oxford University Press, Oxford, 1991, s. 848-849.

${ }^{98}$ Görsel için bkz.; Dumbarton Oaks Resources Byzantine Seals, "Michael vestes and gerokomos (tenth/eleventh century)", https://www.doaks.org/ resources/seals/byzantine-seals/BZS.1947.2.405/view, Trustees for Harvard University, Washington D.C., 2020 [Erișim Tarihi: 25.10.2020].

${ }^{99}$ Görsel için bkz.; Dumbarton Oaks Resources Byzantine Seals, "Michael vestes and gerokomos (tenth/eleventh century)", https://www.doaks. org/resources/seals/byzantine-seals/BZS.1955.1.2547/view, Trustees for Harvard University, Washington D.C., 2020 [Erişim Tarihi: 25.10.2020].

${ }^{100}$ Görsel için bkz; Dumbarton Oaks Resources Byzantine Seals, "Michael vestes and gerokomos (tenth/eleventh century)", https://www.doaks.org /resources/seals/byzantine-seals/BZS.1955.1.2548/view, Trustees for Harvard University, Washington D.C., 2020 [Erișim Tarihi: 25.10.2020].
}

Selanik basımı sikkelerde en erken, imparator I. Aleksios döneminden (1081-1118) örnekler vardır. İki konkav histamenon üzerinde Aziz Demetrios, imparator I. Aleksios ile birlikte temsil edilmiştir. ${ }^{105}$ Tahmini olarak 1081/1082 tarihli ilk örnekte üzerinde asker kostümü ve elinde kılıç yer alan Aziz Demetrios imparatora bir labarum teslim etmektedir (G.9a). İkinci örnekte Aziz Demetrios basamaklar üzerinde yükselen haçı imparatora teslim eder ve bu sikke muhtemelen 1082-1085 y1lları arasına aittir. ${ }^{106}$ Ioannes Dukas Vatatzes dönemine (1222-1254) ait bir bakır trachea üzerinde yer alan Aziz Demetrios tam boy temsil edilmiştir; ayakta duran figür, kalkan ve mizrak tutar (G.9b).

1204-1261 yıllarını kapsayan Latin İstilası evresinde Selanik despotu I. Theodoros Komnenos Dukas dönemine (1224-1230) ait sikkelerde Aziz Demetrios'u tam boy, ayakta ya da büst halinde tekil olarak betimleyen Selanik basımı çok sayıda sikke vardır. Bir örnekte Aziz Demetrios, I. Theodoros'la birlikte Selanik'i sembolize eden bir yap1 maketini tutarken (G.9c); bir başka sikkede aziz, despotu taçlandırmaktadır. Bu dönemde, Konstantinopolis sikkelerinde görülen “imparatoru taçlandıran İsa"nın yerini Demetrios'un aldığına şahit olunur.

Manuel Komnenos dönemine (1230-1237) ait sikkelerde kimi zaman Aziz Demetrios, imparatorla birlikte tahtta otururken temsil edilir ve iki figür aralarında Selanik'i simgeleyen bir maket tutmaktadırlar. Bazı örneklerde Aziz Demetrios büst halinde tekil halde, bazı örneklerde ise yarım boy temsil edilmiş olarak ve yine Manuel'le yanyanadır.

Ioannes Dukas (1237-1244) ve VIII. Mikhail Palaiologos dönemine (1259-1261/1261-1282) ait sikkelerde Aziz Demetrios, I. Theodoros dönemine ait bakır trachea örneklerinde gördüğümüz gibi; imparatorla birlikte büst halinde, yarım ya da tam boy olarak betimlenmiştir. Aziz Demetrios kimi örneklerde taht üzerinde oturmakta ve dizlerinin üzerinde kılıç tutmaktadır (G.9d). II. Andronikos (1282-1328), II. Andronikos-IX. Mikhail (1294-1320) ve III. Andronikos döneminde (1328-1341) Aziz Demetrios en sik betimlenen asker azizdir.

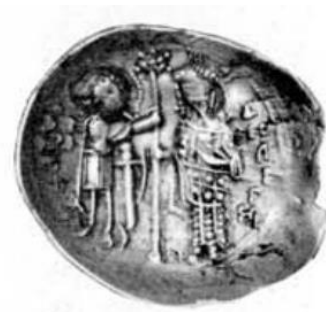

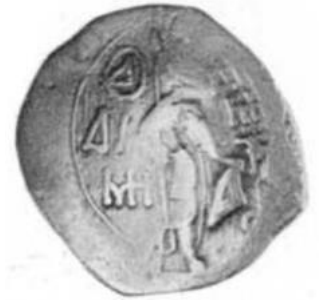

b
101 Arithmos muhafizı. Arithmos hakkında bkz.; M. C. Bartusis, "Arithmos", The Oxford Dictionary of Byzantium I, (ed. A. P. Kazhdan), Oxford University Press, Oxford, 1991, s. 171-172. Komes hakkinda bkz.; A. Kazhdan, "Comes", The Oxford Dictionary of Byzantium I, (ed. A. P. Kazhdan), Oxford University Press, Oxford, 1991, s. 484-485.

${ }^{102}$ Görsel için bkz.; Dumbarton Oaks Resources Byzantine Seals, "Leo komes tou Arithmou (tenth/eleventh century", https://www.doaks. org/resources/seals/byzantine-seals/BZS.1958.106.3423/view, Trustees for Harvard University, Washington D.C., 2020 [Erișim Tarihi: 25.10.2020].

103 Görsel için bkz.; Dumbarton Oaks Resources Byzantine Seals, "Sisinnios/Honorios (?) (twelfth century)", https://www.doaks.org/resources /seals/byzantine-seals/BZS.1951.31.5.2611/view, Trustees for Harvard University, Washington D.C., 2020 [Erişim Tarihi: 25.10.2020].

104 Görsel için bkz.; Dumbarton Oaks Resources Byzantine Seals, "John metropolitan of Thessalonica (ca. 1198)", https://www.doaks.org/ resources/seals/byzantine-seals/BZS.1958.106.10, Trustees for Harvard University, Washington D.C., 2020 [Erișim Tarihi: 25.10.2020].

${ }^{105}$ P. Grierson, Byzantine Coins, University of California Press, Berkeley, Los Angeles, 1982, s. 11, 12, 37, 220.

${ }^{106}$ Grierson, Byzantine Coins, s. 224 


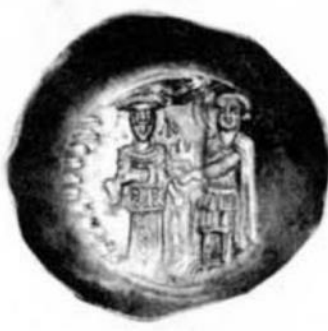

c

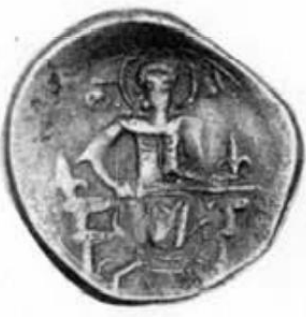

d
G.9.Aziz Demetrios'un yer aldığı sikke örnekleri, [a.I. Aleksios, 1081/1082 / b.Ioannes Dukas Vatatzes, 1222-1254 / c.I. Theodoros Komnenos Dukas, 1224-1230 / d.Ioannes Dukas, 1237-1244] (Grierson'dan).

Bizans ikonalarında Aziz Demetrios'un tasvirlerine 10. yüzyıldan itibaren rastlanır. İkonalarda aziz, sikke ve mühür örneklerinde olduğu gibi asker aziz olarak karşımıza çıkar. Erken örneklerden biri olan 950-1000 civarına tarihlenen fildişinden rölyef bir ikonada tam boy, cepheden, hafif contrapposto duruşunda ve ayakta, asker kostümü içinde, sol elinde kalkan, sağ elinde kılıç tutan asker aziz Demetrios vardır. Figürün başının etrafında bezemesiz bir hale yer alır. Yüz hafif tombul, saçlar küt ve bukleli, kaşlar yay biçimli, burun dar ve uzun, ağız küçük, kulakların üst kavsi büyükçe işlenmiştir. Figürün donuk ifadesi, gövdenin dik ve katı pozisyonu, kılıcını sıkıca kavrayışı figüre askerî bir hava katar. Figür, dizlerine kadar uzanan yarım khlamys üzerine bir klivanion (plakalı zırh), kalça ile uyluklarına ise koruyucu olarak kremasmata kușanmıștır. Figürün sağ omzundan bir fibula ile tutturulan lacerna (pelerin) sol kolu üzerinden kalkanının üzerine doğru sarkar. Göğüs altından bağlanan kuşak, zırhın ağırlığını gövdeye dağıtmak üzere Romalı askerler tarafından, sonrasında ise Bizans ordusunda kullanılmıştır. ${ }^{107}$ Figürün arkasından, sağında diyagonal olarak asılı bir sadak görünür. Azizin başının iki yanındaki boşluğa adı işlenmiştir: $\mathrm{OA}|\Delta \mathrm{HMH}| \mathrm{TPHO \Sigma}$ (Aziz Demetrios) (G.10a-b). Eser günümüzde New York'taki Metropolitan Sanat Müzesi'nde yer alır (env. no.: 1970.324.3).

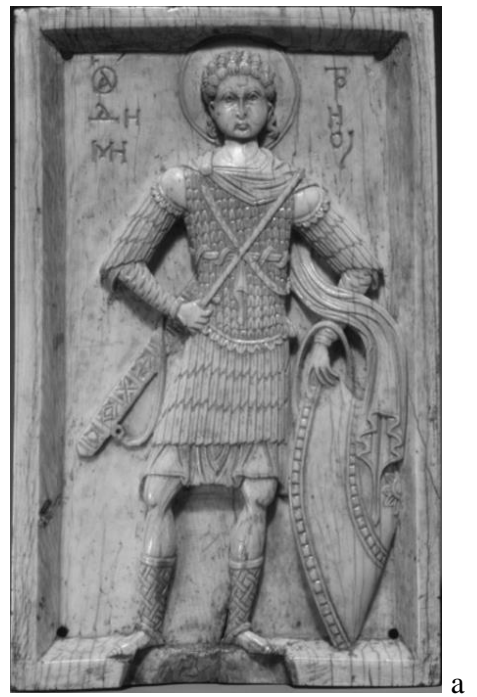

107 Orta Bizans dönemi askeri kıyafetlerine ilişkin bkz.; T. Dawson, "Kremasmata, Kabadion, Klibanion: Some Aspects of Middle Byzantine Military Equipment Reconsidered", BMGS 22, s. 38-50.

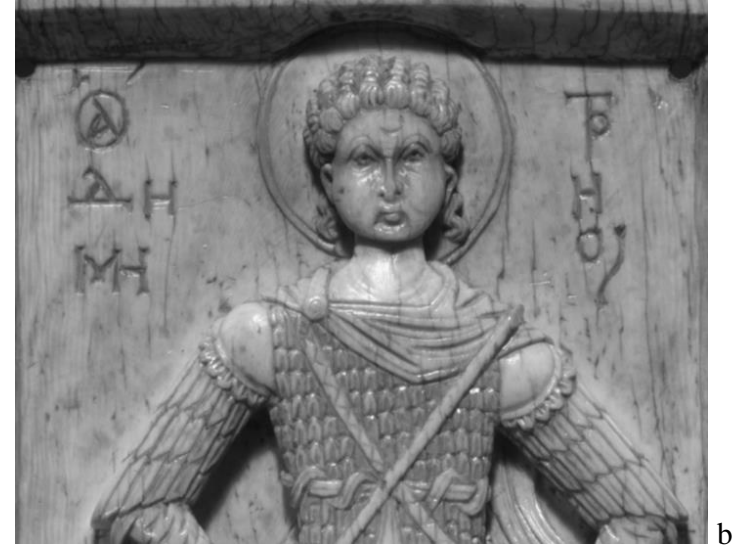

G.10.a.Demetrios, fildişi rölyef ikona / b.detay, 19.7x12.1x1 cm, 950-1000 yılları, env. no.: 1970.324.3, Metropolitan Sanat Müzesi, New York, Amerika Birleșik Devletleri (Evans ve Wixom'dan.

1860'larda Athos'tan St. Petersburg'a getirilen, 1964'te onarım geçirmiş ve bugün St. Petersburg'daki Ermitaj Müzesi’nde bulunan geç 11.-erken 12. yüzyıla ait, ahşap üzerine tempera tekniğindeki bir ikonada Aziz Demetrios, Aziz Georgios ve Theodoros'la birlikte karşımıza çıkar (env. no.: X-333). ${ }^{108}$ Aziz Demetrios en sağda yer alır; figür ön tarafı kısa, arkada, ense kısmına uzanan dalgalı saçlarından, sakalsız oluşundan ayırt edildiği gibi, sağında ve solunda dikey olarak yazılı kitabede de adı geçmektedir: $\mathrm{O}|\mathrm{A}| \Gamma|\mathrm{IO}| \Sigma$ $\Delta|\mathrm{H}| \mathrm{M}|\mathrm{H}| \mathrm{T}|\mathrm{PI}| \mathrm{O} \mid \Sigma$ (Aziz Demetrios).

Altın yaldızlı düz bir zemin üzerindeki figürler kırmızı ve mavinin tonlarıyla ve altın yaldızla renklendirilmis khlamys, klivanion ve lacerna giyer. Aziz Georgios ve Theodoros'un sol elinde kalkan varken; Demetrios'un kalkanı yoktur. Diğer iki asker aziz mızrak tutarken; Aziz Demetrios sol elinde kılıcının kınını tutar. Demetrios sağ elinde kınından çektiği kılıcını göğüs hizasında yukarı doğru kaldırmıştır (G.11a-b).

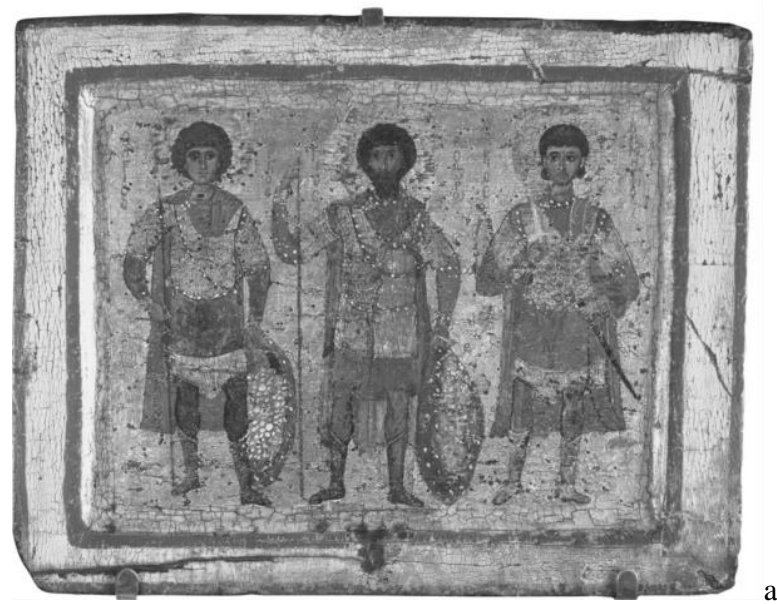

108 A. W. Carr, "Popular Imagery", The Glory of Byzantium Art and Culture of The Middle Byzantine Era A.D. 843-1261, (ed. H. C. Evans ve W. D. Wixom), The Metropolitan Museum of Art-H. N. Abrams, New York, 1997, s. 122. 


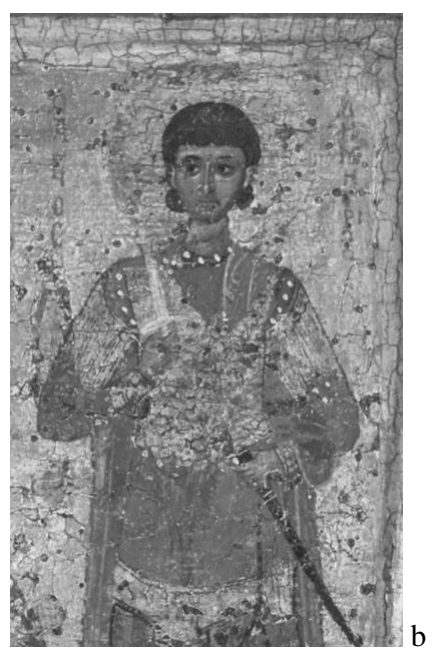

G.11.a.Aziz Georgios, Theodoros ve Demetrios / b.Aziz Demetrios, detay, ikona, $28.5 \times 36 \mathrm{~cm}$, geç 11.-erken 12. yüzyıl, Ermitaj Müzesi, St. Petersburg, Rusya (hermitagemuseum.org).

Şahsi kullanım için hazırlanmış, $3 \times 3 \mathrm{~cm}$ boyutlarındaki bronz üzerine işlenmiş rölyef bir ikonada Aziz Demetrios büst halindedir. Cepheden betimlenen figürün başının çevresinde düz zeminli bir hale yer alır. Asker azizin sağ elinde göğüs hizasından diyagonal olarak yukarı kaldırdığı mızrağı, sağ tarafında ise $1 / 4^{\prime} i$ görünen yuvarlak kalkanı vardır. Başının iki yanında yer alan kitabede $\mathrm{OA}|\Delta| \mathrm{H} \mid \mathrm{MH}$ TPI $|\mathrm{O}| \Sigma$ (Aziz Demetrios) yazmaktadır (G.12).

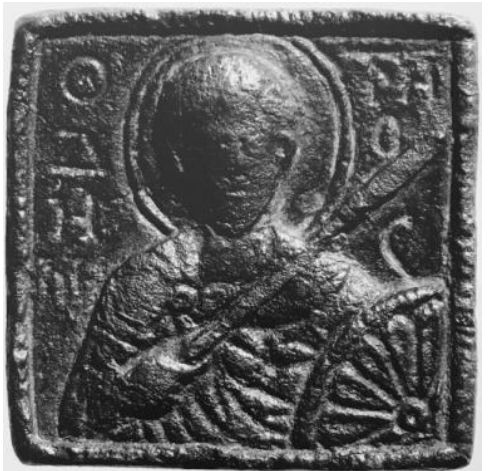

G.12.Aziz Demetrios, bronz ikona, 14. yüzyıl, Bizans Kültürü Müzesi, Selanik, Yunanistan (Nalpantis'ten).

Venedik'teki San Marco Kilisesi'nin batı cephesinde yer alan mermer üzerine işlenmiş, rölyef panoda Aziz Demetrios bu kez bir taht üzerinde oturmaktadır; ayakları bir platform üzerindedir. Figürün başının çevresinde düz zeminli bir hale vardır. Kısa saçları kulaklarını açıkta bırakır. Yüz hafif tombuldur, burun dar ve uzundur; ağız ve yüzün bir kısmı tahrip durumdadır. Dizlerini açıkta bırakan khlamysin üzerine bir klivanion giyen figürün önde, gögüs hizasının biraz üstünde, ortadan bir fibula ile tutturulmuş lacerna kuşandığı görülür. Göğüs altından vücudunu dolaşan kuşak, önde düğüm oluşturur ve zırhın ağırlığını hafifletir. Yukarıda değindiğimiz bazı sikke örneklerinde olduğu gibi oturan Aziz Demetrios'un dizleri üzerinde tuttuğu kılıcı, tipik bir ikonografik şema olmuştur. Burada figür sağ

${ }^{109}$ K. Hoffmann, The Year 1200 II: A Background Survey, (ed. F. Deuchler), The Metropolitan Museum of Art, New York, 1970, no.217.

${ }^{110}$ C. Walter, The Warrior Saints In Byzantine Art And Tradition, Ashgate, Aldershot, Hants, 2003, s. 90.

${ }^{111}$ Theodoros Mezmuru'na ilişkin bkz.; S. der Nersessian, L'Illustration des Psautiers Grecs du Moyen Age II: Londres, Add. 19.352, Bibliothèque des Cahiers Archéologiques 5, Paris, 1970; J. C. Anderson, "On The Nature of Theodore Psalter", The Art Bulletin 70(4), 1988, s. 550-568; I. Hutter,

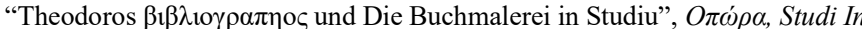
Onore Di Mgr. Paul Canart Per Il LXX Compleanno, (ed. S. Lucà ve L. eliyle kılıcının kabzasını sıkıca kavramıștır, kınını sol eliyle tuttuğu kılıcını hafifçe kınından çektiği dikkati çeker. Figürün baş hizasında, iki yanda Latince olarak azizin adı işlenmiştir: S|C|S DI|MI|TRI|VS (Sanctus Dimitrius/Aziz Demetrios) (G.13a-b). San Marco'daki Aziz Demetrios figürü sikke, mühür, fildişi ve ahşap ikonalarda görülen Demetrios'tan daha heybetli ve her ne kadar vücudun ișlenișinde belirli oranda deformasyon olsa da, daha gerçekçi ve daha kaslıdır.

K. Hoffmann, panelin Latin İstilası döneminde (1204-1261), olasılıkla Venedikli bir patron için yapıldığını, Konstantinopolis'ten devşirme ve erken 13. yüzyıla ait olduğunu belirtir. ${ }^{109} \mathrm{C}$. Walter, bu panonun 12. yüzyıldan daha geç olamayacağını iddia eder. ${ }^{110}$
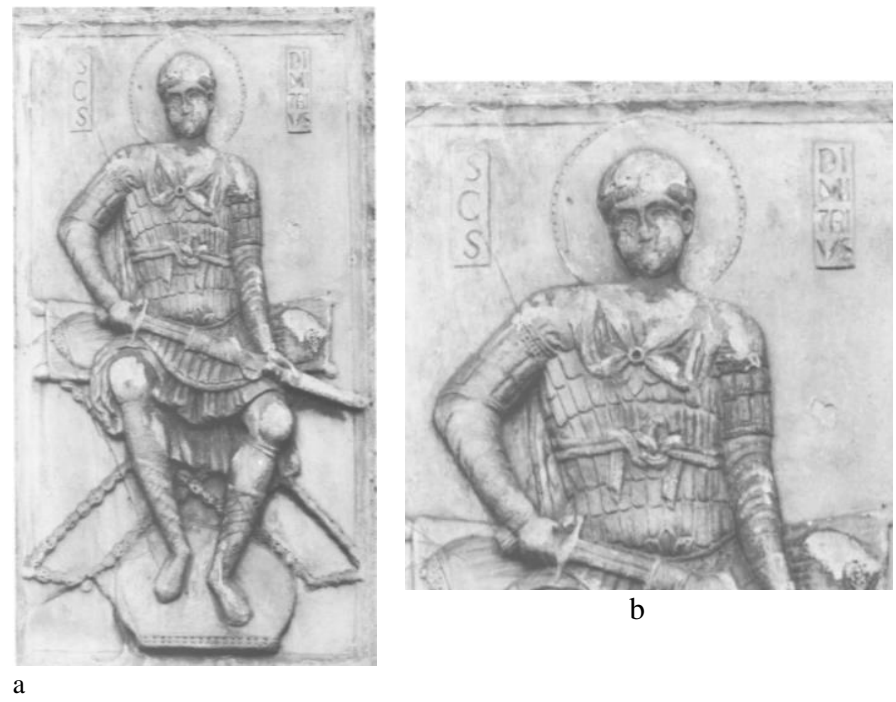

G.13.a.Aziz Demetrios / b.detay, mermer rölyef, San Marco Kilisesi, Venedik, İtalya (Hoffman'dan).

Aziz Demetrios el yazmalarının resimlerinde çok sık görülmemekle birlikte, 11. yüzyıldan iki Mezmurlar Kitabı (Psalter) nüshasında karşımıza çıkar. Konstantinopolis'teki Stoudios Manastırı'nın scriptoriumunda, manastırın kâtip, ressam ve keşişi Theodoros tarafindan kaleme alınan, 1066 tarihli Theodoros Mezmuru'nda (env. no.: Add MS 19352, British Library, Londra) ${ }^{111}$ folyo 13verso üzerindeki marj resminde (soldan sağa) Aziz Teodoros, Aziz Demetrios ve Aziz Georgios betimlenmiştir. Figürlerin başının çevresinde kırmızı konturla çevrelenmiş ve altın yaldızdan, düz zeminli birer hale vardır. Her figür ayakta durur ve cepheden gösterilmiştir. Figürler, omuzları, manşetleri ve etek ucu soyut/bitkisel motiflerle nakışlı bordürlerle süslü, uzun tunik giyerler. Tunik üzerine, figürlerin sağ tarafindan bir fibula ile tutturulmuş paludamentum kuşanmışlardır. Aziz Theodoros ve Georgios'un sol eli paludamentumun altına gizlenmiştir ve birer kapalı kodeks tutmaktadırlar. Figürlerin sağ elleri yumruk biçiminde, sol elle taşınan kodeksi desteklemektedir. Her bir figürün başının hemen üzerinde kırmızı mürekkeple adları işlenmiştir: $\mathrm{O} \alpha|| \Theta \varepsilon|\hat{o}| \delta \omega \mid(\dot{o} A \gamma ı$ '

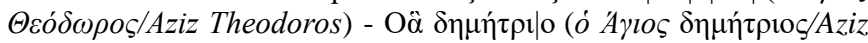

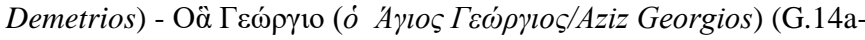
b).

Aziz Demetrios bu kitap resminde -yaygın betimlenişinin aksinesakallı-bıyıklı olarak, sivil giysiler içinde ve orans pozisyonunda

Perria), Bollettino Della Badia Greca Di Grottaferrata 51, 1997, s. 177-208; C. Barber (ed.), Theodore Psalter, Electronic Fascimile (CD ROM), University of Illinois Press, Champaign, 2000; C. Barber, "Readings in the Theodore Psalter", a.y. içinde, s. 1-33; C. Barber, "In The Presence Of The Text: A Note On Writing, Speaking And Performing In The Theodore Psalter", Art And Text In Byzantine Culture, (ed. L. James), Cambridge University Press, New York, 2007, s. 83-99; İ. Kaya Zenbilci, Orta Bizans Dönemi Konstantinopolis Manastır Atölyeleri ve Resimli El Yazmalart Üretimi, Basılmamıs Doktora Tezi, Ankara Üniversitesi Sosyal Bilimler Enstitüsü Sanat Tarihi Anabilim Dalı, 2017, s. 193-290. 
temsil edilmiştir (G.14b, detay). Theodoros Mezmuru'nda yer alan bu resmin paralel örneği 11. yüzyılın ikinci yarısı/üçüncü çeyreğine ait Barberini Mezmuru'nda (env. no.: Barb. gr. 372, Vatikan Apostolik Kütüphanesi, Vatikan) ${ }^{112}$ folyo 23verso'da karşımıza çıkar. ${ }^{113}$ Orans pozisyonundaki Aziz Demetrios'un en erken tarihli örneği Selanik'teki Aziz Demetrios Kilisesi'nin, 1917 yangını öncesinde belgelenmiş, kuzey iç nef arkad mozaikleri arasında yer almaktaydı (G.7c). Ne var ki bu mozaikler günümüze ulaşamadan yok olmuştur. Yapıdaki güney batı payenin doğu yüzünde tekrar karşımıza çıkan aziz, bir çocuğun Aziz Demetrios'a teslim edilmesi sahnesinde yine orans pozisyonundadır (G.8b). Bu mozaiklerin Selanik'teki Aziz Georgios Rotondu mozaiklerindeki orans duruşunda betimlenmiş aziz figürlerine öykündüğü düşünülebilir.

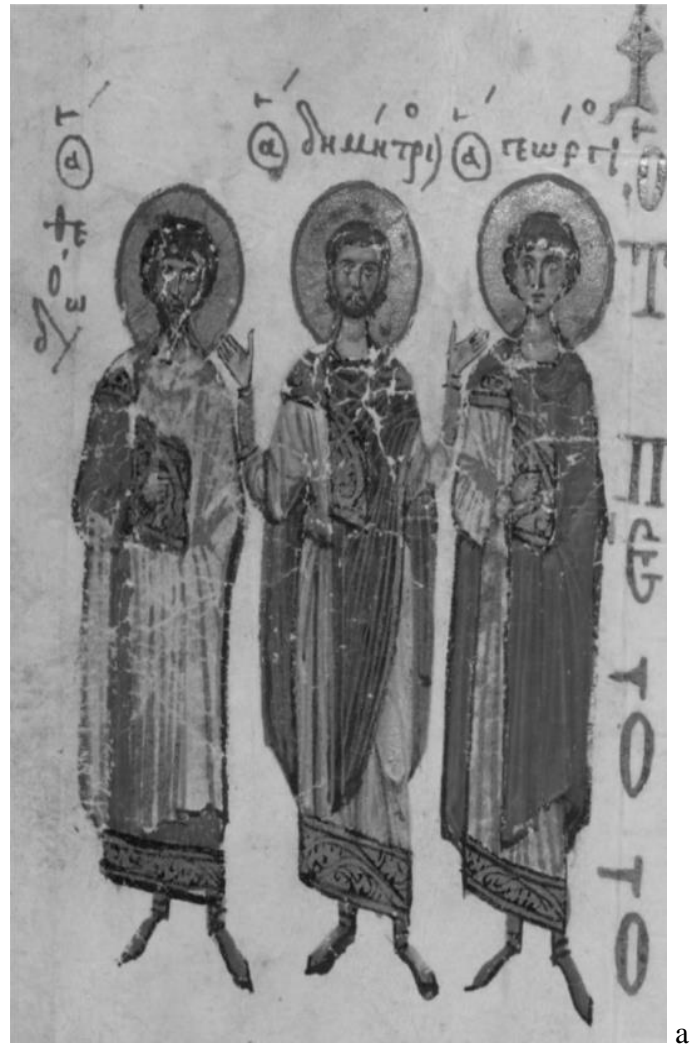

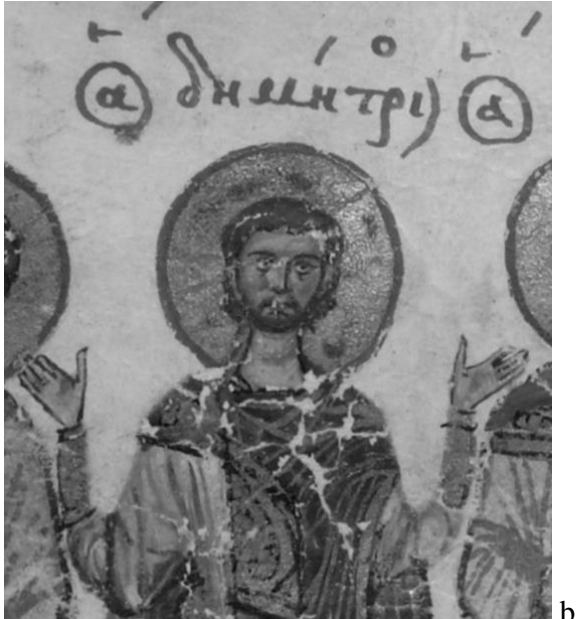

G.14.a.Aziz Theodoros, Aziz Demetrios, Aziz Georgios / b.Aziz Theodoros, detay, Theodoros Mezmuru, folyo 13verso, 1066 y1lı, Stoudios Manastırı, Konstantinopolis (env. no.: Add MS 19352@, British Library, Londra) (bl.uk)

Theodoros Mezmuru'nda folyo 125verso üzerinde ünik bir konu yer alır. Burada, imparator Maksimianus'un favorisi olan gladyatör Lyeus'un Nestor tarafından öldürülmesiyle ilişkili yukarıda değindiğimiz hikâye görselleștirilmiştir. Konular ve figürler aynı zamanda kitabelerle tanımlanmıştır:

\section{IC XC / $\dot{I} s a$}

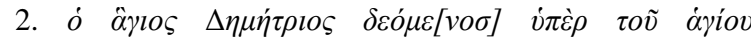

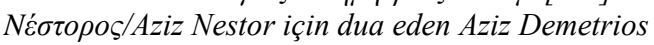
Aziz Nestor

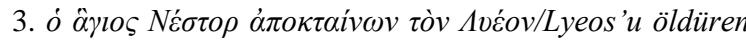

\section{4. ó Avéos /Lyeos}

\section{5. $\dot{\beta} \beta \alpha \sigma \lambda \varepsilon \varepsilon \dot{\varsigma} \varsigma \lambda v \pi o v ́ \mu \varepsilon[v o \sigma] /$ Kederlenen imparator}

Sol marjda üstte, İsa ikonası önünde Aziz Demetrios (G.15a-b), altta Aziz Nestor'un gladyatör Lyeus'u mızrakla öldürmesi (M.S. 4. yüzyıl başı) ve alt marjda imparator Maksimianus ve Lyeus'un ölümünü imparatora haber veren ulak yer alır (G.15a).

İsa ikonası ile jestleriyle iletişim halinde olan folyo 125versodaki Aziz Demetrios folyo 13verso üzerindeki tasviriyle (G.14a-b) aynı tiptedir.

Resimler, Septuagint-Mezmur 93:1'de geçen “Aĩvos $\dot{\omega} \delta \tilde{\eta} \varsigma \psi \alpha \lambda \mu \grave{o}[\varsigma]$

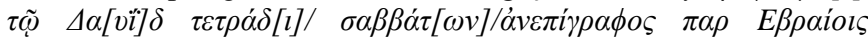
$Q \gamma^{\prime} / \Theta[\varepsilon \dot{\delta}] \varsigma \quad \dot{\varepsilon} \kappa \delta \imath \kappa \eta ́ \sigma \varepsilon \omega v \quad \kappa[\dot{\rho} \rho \imath] \varsigma / \Theta[\varepsilon \dot{\varepsilon}] \varsigma \quad \dot{\varepsilon} \kappa \delta \imath \kappa \dot{\sigma} \sigma \varepsilon \omega v$

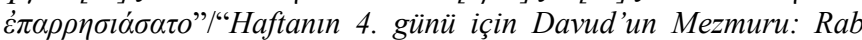
intikam tanrısıdır, intikam tanrısı kendini ilan etti" şeklindeki metinle

\footnotetext{
112 Barberini Mezmuru'nun, paleografik ve kodikolojik özelliklerine dayalı olarak, Stoudios Manastırı'nın katip, ressam ve keşişi Kaesarealı Theodoros tarafından kaleme alındığı ileri sürülür, bkz.; I. Spatharakis, The Portrait in Byzantine Illuminated Manuscripts, E. J. Brill, Leiden, 1976, s. 31-32. Folyo 4verso ve 5recto üzerindeki iki epigramın Mikhail Psellos'a ait olduğu ve Psellos'un aynı zamanda kitabın siparișini veren kiși olduğuna dair bkz.; A Paul, "Historical Figures Appearing in Epigrams on Objects", Poetry and Its Context in Eleventh-Century Byzantium, (ed. F. Bernard, K. Demoen), Ashgate, 2012, s. 92. "Bazl araștırmactlar tarafindan el yazması, X Konstantinos Doukas (1059-1067) döneminde VII. Mikhail'in 1060 yllinda babasıly müsterek imparator olarak taç giymesi fikrinden yola çıkılarak, bu döneme tarihlendirilir. Bir başka grup araştırmacı IV. Romanos'un 1067'deki
}

taç givmesi ile el yazmasına iliskin bir tarih önerisinde bulunur. Bir diğer grup araştırmacı ise el yazmasını Aleksios Komnenos (1081-1118) dönemini kapsayan 1092 yllına atfeder"; Kaya Zenbilci, Konstantinopolis Manastır Atölyeleri, s. 111. Esere ilişskin ayrıca bkz.; J. C. Anderson, "The Date and Purpose of The Barberini Psalter", Cahiers Archeologiqués 31, 1983, s. 3567; J. C. Anderson, C. Walter, P. Canart, The Barberini Psalter: Codex Vaticanus, Barberinianus Graecus 372, Belser Inc., Zürih, New York, 1989; Kaya Zenbilci, Konstantinopolis Manastır Atölyeleri, s. 290-343.

113 Görsel için bkz.; DVL-Digivatlib, "Manuscript-Barbr.gr.372", https://digi.vatlib.it/view/MSS_Barb.gr.372, Biblioteca Apostolica Vaticana, Vatikan. 
ilişkilendirilmiştir. Metin resim ilişkisi mavi mürekkeple yapılmış bir işaretçi ile sağlanmıştır. ${ }^{114}$
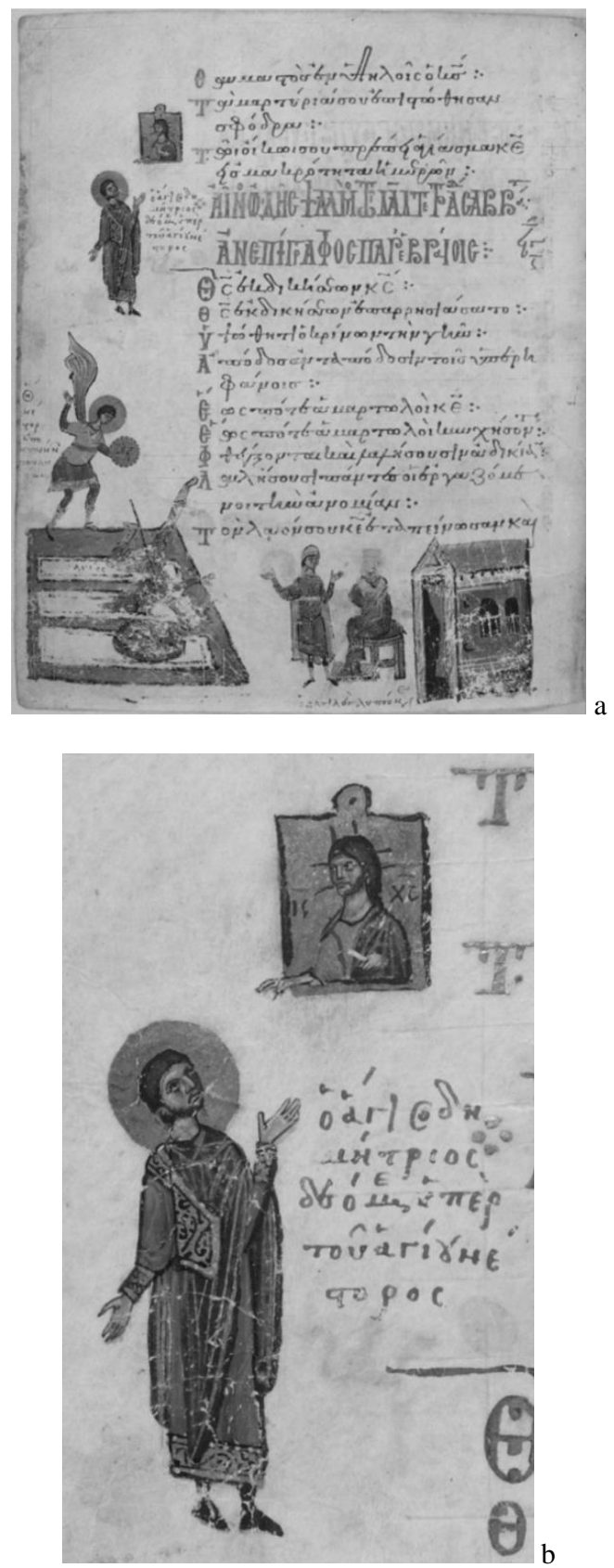

G.15.a.İsa ikonası önünde Aziz Demetrios (sol marj üst), Aziz Nestor’un Lyeus'u öldürmesi, (sol ve alt marj), İmparator Maksimianus ve ulak (alt marj) / b.İsa ikonass önünde Aziz Demetrios, detay, Theodoros Mezmuru, 1066 y1l, StoudiosManastır1 scriptorium'u, Konstantinopolis (env. no.: Add MS 19352@, British Library, Londra) (bl.uk).

Aziz Demetrios kültüyle ilişki olarak Selanik'te ve Balkanlar'da ele geçen en önemli eser grubu koutrouvialardır (hacı matarası). Bu eserlerin bir yüzünde sıklıkla Aziz Demetrios'un portresinin işlendiği görülmektedir.

Azizin mezarını ziyaret edenler, bir yüzünde Demetrios'un, diğer yüzünde ise Meryem'in, Aziz Nestor'un, Aziz Georgios'un veya Azize Theodora'nın yer aldığı seramik veya kurşundan yapılmış ${ }^{15} \mathrm{bu}$ objeleri mür yağı ile doldurarak, beraberlerinde ülkelerine götürmüş olmalıdırlar. 13. yüzyıla ait, bir yüzünde Aziz Demetrios diğer yüzünde ise Azize Theodora'nın yer aldığı kurşundan bir koutrouvia
Selanik'teki Bizans Kültürü Müzesi’nde yer alır (env. no.: BA 74/13). Yarım boy olarak, başının çevresi haleli asker aziz olarak temsil edilen Demetrios mızrak tutmaktadır (G.16). Aynı döneme ait paralel bir eser ise Kavala Arkeoloji Müzesi'ndedir. Aziz Demetrios başının çevresindeki hale, üzerindeki zırhı, sağ elindeki mızrağ 1 ve solunda tuttuğu kalkanıyla asker aziz olarak tasvir edilmiştir (G. 17). Her iki eserin hafif şişkin yuvarlak gövdeli, uzun konik-silindirik boyunlu formu, çift kulplu oluşu ve üzerinde yer alan diyagonal çizgilerle oluşturulmuş geometrik süslemeler aynı üretim merkezini işaret etmektedir.

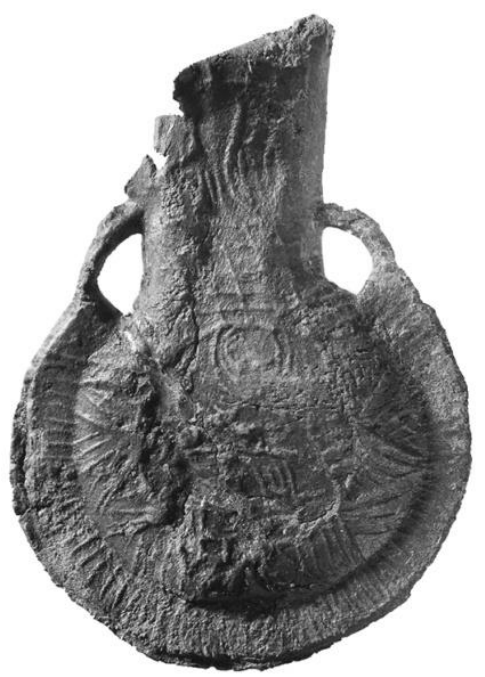

G.16. Aziz Demetrios, hacı matarası, 13. yüzyıl, Bizans Kültürü Müzesi, Selanik, Yunanistan (Nalpantis’ten).

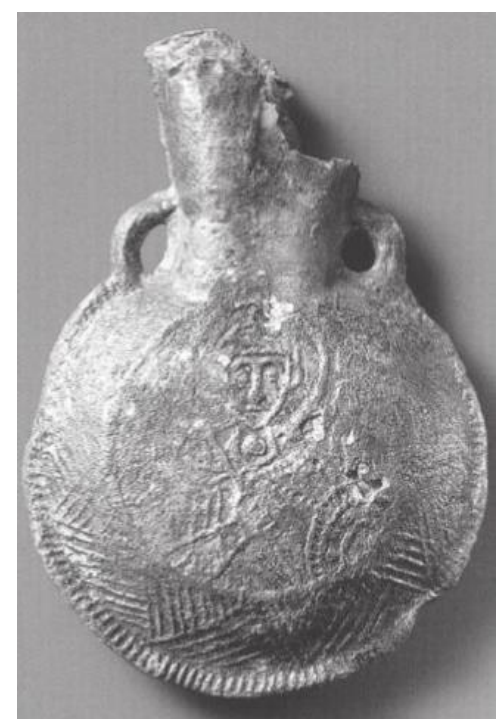

G.17. Aziz Demetrios, hacı matarası, 13. yüzyı1, Kavala Arkeoloji Müzesi, Yunanistan (Krueger'den).

Aziz Demetrios Kilisesi'nin kryptasında gerçekleştirilen kazılarda, içinde -merkezinde- Demetrios'un monogramının işlendiği çok sayıda sırlı kâse ele geçmiştir. Günümüzde, tümüyle korunmuş iyi bir örnek, Selanik'teki Bizans Kültürü Müzesi koleksiyonunda bulunmaktadır (G.18). Chersonessos kazılarında ele geçen Aziz Demetrios tasvirli ve 13.-14. yüzy1llara tarihlenen sırlı bir kâse bugün St. Petersburg'daki Ermitaj Müzesi'ndedir (env. no.: X-333) (G.19). Selanik'te ele geçen ve 14. yüzyıla ait bir başka örnek ise Selanik'teki Bizans Kültürü Müzesi'nde bulunmaktadır (G.20).

13. yüzyılın ikinci yarısından daha eski olmayan bu seramik kaplar, azizin mezarını ziyaret eden hacılarla birlikte ülkelerine dönmüş; 
Konstantinopolis'te ve Varna'da bulunmuştur. ${ }^{116}$ Kapların kullanımı olasılıkla kilisedeki, kutsal kabul edilen, mür kaynağ ${ }_{1}$ ile ilişkilidir. ${ }^{117}$ Aynı zamanda, Geç Bizans dönemine ait kaplarda aziz tasvirleri nadir olsa da Demetrios'un Selanik'te ve yakın çevresinde ele geçen 13. 14. yüzy1la ait bir dizi kap üzerindeki tasviri, azizin kültünün Geç Bizans Dönemi'nde önemini sürdüğünü göstermektedir.

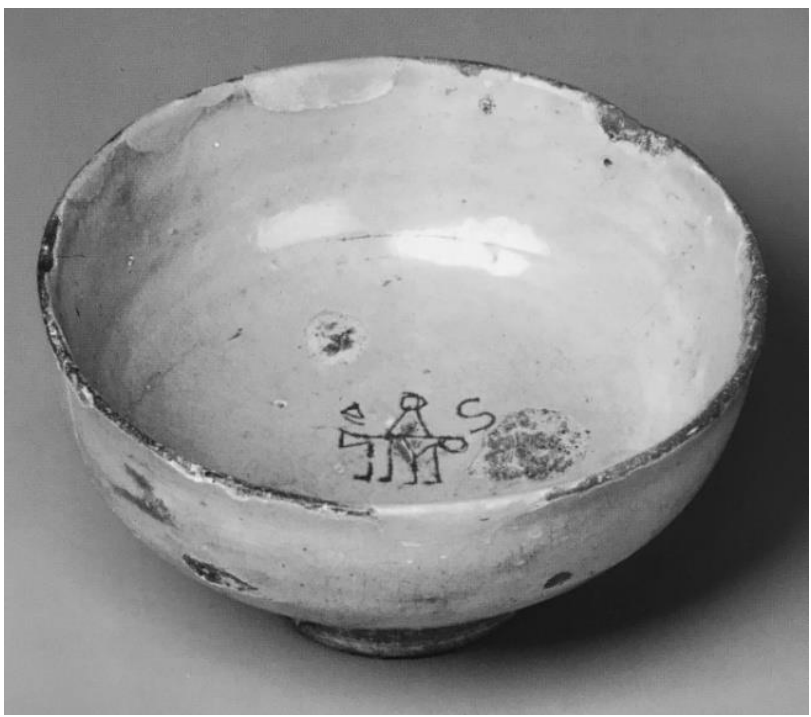

G.18.Aziz Demetrios'un monogramının işlendiği sırlı kâse, 14. yüzy1l Bizans Kültürü Müzesi, Selanik, Yunanistan (Nalpantis’ten).

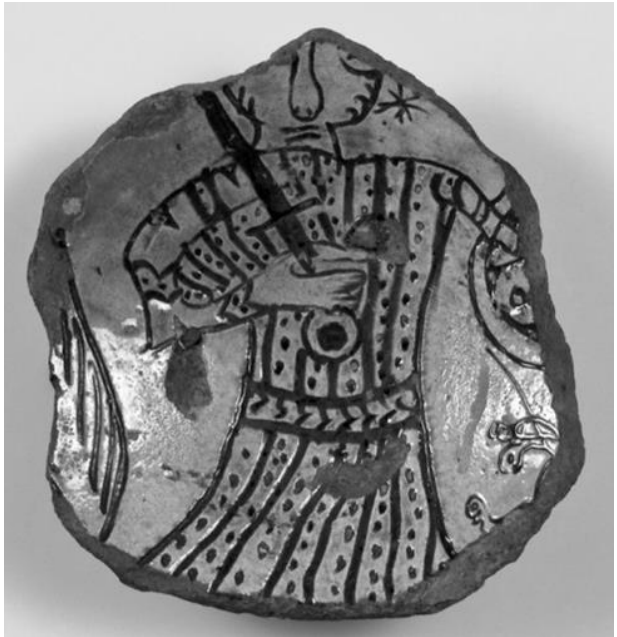

G.19.Aziz Demetrios tasvirli sırlı kap parçası, 13.-14. yüzyıl, Chersonessos buluntusu, Ermitaj Müzesi, St. Petersburg, Rusya (hermitage museum.org).

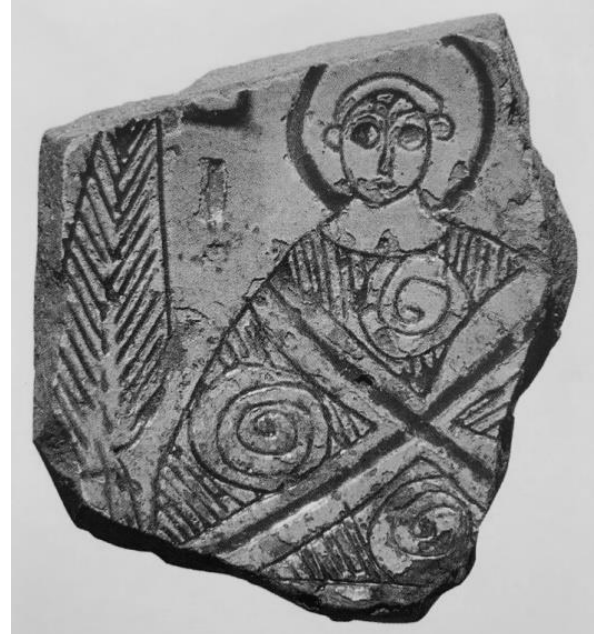

G.20.Aziz Demetrios tasvirli sırlı kap parçası, 14. yüzyıl, Bizans Kültürï Müzesi, Selanik, Yunanistan (Nalpantis’ten).

\section{Sonuç}

Selanik kentinin koruyucu azizi, Aziz Demetrios'un kökeni uzun zaman tartı̧̧ma konusu olmuştur. Tartışmaların temel nedenlerinden ilki ilk șehitlik derlemesi olan Süryani Breviarum'u ve bu metne dayanılarak yazılan ikinci şehitlik derlemesi sözde-Martyrologium Hieronymianum'dur. Her iki eserde de azizin adı geçmemektedir. Dolayısıyla Aziz Demetrios'un erken şehitlik derlemelerinde yer almayışı, azizin kökeninin pagan kültlerle ilişkilendirilmesi yönünde bazı girişimlere neden olmuştur. Bu girişimler 19. yüzyıla denk gelir.

H. Usener, Demetrios için 20-28 Ekim arasında yapılan Demetria festivali ile yılın aynı zamanında yapılan İyonyalı Apaturia festivaline dayanarak Aziz Demetrios'u Dionysios'la ilişkilendirmiştir. H. Gelzer, Demetrios'a biçilen unvan ve rolün daha önceki pagan dinine dayandığını belirtir. E. Lucius, Makedonya, Teselya ve Yunanistan'da kültü yaygın hale gelmiş işçilerin Tanrısı Kabirus'u (Kabeiroi) Demetrios'la ilişkilendiren ilk kişidir ve iddiası iki figür arasındaki savaşçı karakterin benzediği yönündedir. C. Edson, Tanrı Kabirus kültü ile Aziz Demetrios kültü arasında daha az kapsamlı bir bağlantı kurar; Kabirus kültünün bazı unsurlarının, sonradan, Hiristiyan kentinde Aziz Demetrios kültünün üstlendiği karakteristik biçime katkıda bulunmasının mümkün olduğunu vurgular. ${ }^{118}$

Azizin kökenine dair ikinci sorun, Selanik'in yerel azizinin tasvirinin kentteki erken Bizans evresine ait Aziz Georgios Rotondu'ndaki mozaiklerde betimlenen martyrler arasında yer almayışıdır. Üstelik mozaiklerde temsil edilen azizleri tanımlayan kitabelerden bir kısmının bugün tahrip durumda olması nedeniyle, azizlerden birinin anonim kalması da bir başka sorundur ve bu anonim aziz, Demetrios ile ilişkilendirilememiştir.

Bir başka sorun, 7. yüzyıla ait, Aziz Demetrios'un adının geçtiği ilk Bizans metni olan Aziz Demetrios'un Mucizeleri'nde Leontios adl bir validen (eparkhos) söz edilmesi ve bu kişinin 5. yüzyılın başlarında İlirya valiliği yapmış Leontios ile karıştırılmış olmasıdır. Burada ortaya bir başka problem daha çıkar: Aziz Demetrios'un Sirmium kökenli olup olmadığı. Çünkü söz konusu Leontios'un 5. yüzyılın başlarında Sirmium ile Selanik arasındaki zorunlu seyahatleri azizin röliklerinin Selanik'e hâlihazırda Sirmium'dan getirilmiş olabileceği görüşüne neden olmuştur. Üstelik Aziz Demetrios Kilisesi'nde, azizin röliklerinin gömülü olduğu düşünülen

\footnotetext{
${ }^{116}$ Bakirtzis, "Pilgrimage to Thessalonike", s. 186.

${ }^{117}$ D. Nalpantis, Museum of Byzantine Culture Archaeological Guide, Atina, 2018, s. 141.
}

${ }^{118}$ Vickers, "Sirmium or Thessaloniki", s. 343-344. 
kryptada azize dair herhangi bir ize rastlanmamış; dolayısıyla bu arkeolojik sonuç Demetrios'un buraya gömülmüş olduğu iddiasını ortadan kaldırmıştır.

Bir diğer sorun, Aziz Demetrios Kilisesi'nin ilk inşa ve mozaik evresiyle ilişkilidir. Bizans yazılı kaynakları ile mimariye dayalı üslup yorumlamalarından yapılan çıkarımlar 5. yüzyılın sonları-6. yüzyılın başları civarında örtüşmektedir. Dahası erken evrede Aziz Demetrios'un tasvirlerine, adına inşa edilen Selanik'teki kilisenin duvar mozaikleri dışında, başka yerde rastlanmaz.

Aziz Demetrios'a ilişkin, Mucizeler dışında, hagiografik metinlerin 9. yüzyıldan itibaren ortaya çıkışı ilginçtir. Burada, 9. yüzyılda ne türden bir olay yaşanmış olduğu ve azizin mucizelerini de içeren kapsamlı biyografísinin neden Mucizeler'den yaklaşık iki yüz yıl kadar sonra yazıldığı soruları akla gelir. Bu anlamda ilk biyografik metin, anonim yazarlı ve nerede yazıldığı belli olmadığ 1 için, azizin kültünü canlandıracak bir girişimin neye ya da kime hizmet ettiğini kestirmek güçtür. Üstelik azizin mür yağıyla ilişkili kültü, Skylitzes'in metnine göre 1040 yılında belirir. Anlaşılan o ki; kentte yaşanan Bulgar istilasına karşı Selanikliler düşmanları zahmetsizce kentten göndermenin yolunu Aziz Demetrios'un efsanevi varlığ 1 , mucizevî savaşçı gücü ve azizin röliklerinden geldiğine inanılan mür yağından yararlanarak bulmuşlardır. Olasılıkla, Aziz Demetrios'un mucizevî koruyuculuğu meselesi 904 yılındaki Selanik kuşatması sırasında da ortaya çıkmıştır. Ancak bunu destekleyecek tarihi bir veri yoktur.

Aziz Demetrios, Bizans Sanatı'nda 10. yüzyıldan itibaren "asker aziz" olarak belli bir ikonografik şema içinde karşımıza çıkmaktadır. Ancak el yazmalarındaki bazı tasvirler, azizin asker olarak değil, sivil bir aziz olarak temsil edildiği nadir örneklerdir.

11. yüzyıldan itibaren Bizans mühürlerinde Demetrios'un sıklıkla betimlendiği görülür. 10. yüzyıl mühürlerinde figür genellikle büst halinde ve asker aziz olarak temsil edilirken; 11. yüzyılda tam boy ve yine asker aziz olarak betimlendiği örnekler artmaya başlar. Bizans sikkelerinde Aziz Demetrios'un tasvirleri ise ilk kez 11. yüzyılın ikinci yarısından itibaren Selanik basımı sikkeler üzerinde ortaya çıkar. Bunun nedeni, Norman istilası sırasında Bizans kontrolü altında kalan kentin imparator I. Aleksios'un seferlerinin merkez üssü olması nedeniyle, tehditkâr koşullarda orduya ödeme yapmak üzere gereken paranın yerinde basımıla ve öte yandan kentin koruyucu azizinin imgesinin haklı olarak seçilmesiyle ilişkilidir. Ancak Konstantinopolis ve Trabzon basımı kimi sikkelerde de Aziz Demetrios'un tasvirlerine rastlanır.

Özellikle 13.-14. yüzyılda Aziz Demetrios'un kültü doruk noktasına ulaşmıştır. 13. yüzyıldan itibaren azizin mezarının mür yağıyla ilişkili olarak ziyaretçi akınına uğradığı ve insanların şifa bulmak ve azizin mucizevî gücünden yararlanmak üzere kendilerini mür yağı ile mesh ettikleri doğrudan Bizans kaynaklarında anlatılmaktadır. Aziz Demetrios tasvirli hacı mataraları (koutrovia) ve seramikler, azizin monogramının yer aldığı kaplar Demetrios'un mür yağı kültü ile ilişkili objelerdir. Bu objelerin alıcıları ve kullanıcıları vasıtasıyla, Aziz Demetrios'un kültü Balkanlar'a taşınmıştır. 


\section{KAYNAKÇA}

Acerbi, F. ve Gioffreda, A.; "Manoscritti Scientifici della prima età Paleologa in Scrittura Arcaizzante”, Scripta 12, 2019 , s. 9-52.

Alföldi, A.; Der Untergang der Römerherrschaft in Pannonien II, Berlin, Leipzig, 1926.

Anderson, J. C.; “The Date and Purpose of The Barberini Psalter”, Cahiers Archeologiqués 31, 1983, s. 35-67.

Anderson, J. C.; "On The Nature of Theodore Psalter”, The Art Bulletin 70(4), 1988, s. 550-568.

Anderson, J. C.; Walter, C.; Canart, P.; The Barberini Psalter: Codex Vaticanus, Barberinianus Graecus 372, Belser Inc., Zürih, New York, 1989.

Bakirtzis, C.; "Pilgrimage to Thessalonike: The Tomb of St. Demetrios", Dumbarton Oaks Papers 56, 2002, s. 175-192.

Bakirtzis, C. ve Mastora, P.; "Are the mosaics in the Rotunda in Thessaloniki linked to its conversion into a Christian church?”, IX. International Symposium 'Niš and Byzantium', Niš, 3-5 June 2010, Niš, 2011, s. 33-45.

Baldwin B. (İngilizce'ye çev.); Timarion, Wayne State University Press, Detroit, 1984.

Barber, C. (ed.); Theodore Psalter, Electronic Fascimile (CD ROM), University of Illinois Press, Champaign, 2000.

Barber, C. "Readings in the Theodore Psalter", Theodore Psalter, (ed. C. Barber), Electronic Fascimile (CD ROM), University of Illinois Press, Champaign, 2000, s. 1-33.

Barber, C. "In The Presence Of The Text: A Note On Writing, Speaking And Performing In The Theodore Psalter", Art And Text In Byzantine Culture, (ed. L. James), Cambridge University Press, New York, 2007, s. 83-99.

Bartusis, M. C.; “Arithmos”, The Oxford Dictionary of Byzantium I, (ed. A. P. Kazhdan), Oxford University Press, Oxford, 1991, s. 171-172. Bianconi, D.; "Libri e mani. Sulla formazione di alcune miscellanee dell'età dei Paleologi”, Il codice miscellaneo. Tipologie e funzioni. Atti del Convegno internazionale (Cassino, 14-17 maggio 2003), Segno e testo 2, 2004, s. 311-363.

Bije, C. de; "De S. Demetrio Martyre Thessalonicæ In Macedonia Commentarius Prævius”, Acta Sanctorum Octobris IV, Brüksel, 1780, s. 5052.

Bije, C. de; "Passio Prima Ab auctore anonymo scripta atque ab Anastasio Bibliothecario è lingua Græca in Latinam conversa", Acta Sanctorum Octobris IV, Brüksel, 1780, s. 87-89.

Bije, C. de; "Passio Altera Auctore anonymo a, E Bibliotheca Vaticanæ codice 821", Acta Sanctorum Octobris IV, Brüksel, 1780, s. 90-95.

Bije, C. de; "Passio Tertia S. Demetrii M. Auctore Simeone Metaphraste, E Græco bibliothecæ Chrsitianissimi regis Medicæo exemplari, cum Lipomani et Surii editionibus collato”, Acta Sanctorum Octobris IV, Brüksel, 1780, s. 96-104.

Canart, P. ve Perria, L.; "Les écritures livresques des XI et XII siècles”, Paleografia e codicologia greca (Atti del II Colloquio internazionale Berlino-Wolfenbüttel, 17-20 ottobre 1983), Alessandria, 1991, s. 67-116.

Carr, A. W.; "Popular Imagery", The Glory of Byzantium Art and Culture of The Middle Byzantine Era A.D. 843-1261, (ed. H. C. Evans ve W. D. Wixom), The Metropolitan Museum of Art-H. N. Abrams, New York, 1997, s. 113-184.

Chiesa, P.; Le versioni latine della Passio sanctae Febroniae-Storia, metodo, modelli di due traduzioni agiografiche altomedievali, Spoleto, 1990.

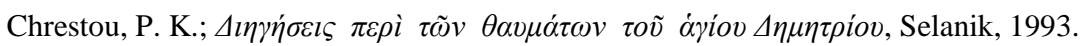

Ćurčić, S.; Some Observations and Questions Regarding Early Christian Architecture in Thessaloniki, Ephoreia of Byzantine Antiquities of Thessaloniki, Selanik, 2000.

Cormack, R. S.; “The Mosaic Decoration of St. Demetrios, Thessaloniki: A Re-Examination in The Light of The Drawings W. S. George”, The Annual of the British School at Athens 64, 1969, s. 17-52.

Dawson, T.; "Kremasmata, Kabadion, Klibanion: Some Aspects of Middle Byzantine Military Equipment Reconsidered”, BMGS 22, s. 38-50. Delehaye, H.; Les Légendes Gresques des Saints Militaires, Paris, 1909.

Dyggve, E.; Recherches sur le Palais Impérial de Thessaloniki, Kopenhag, 1953.

Džurova, A.; “L'enluminure de l'évangéliaire oncial Beratinus 3 de Tirana. Notes preliminaries”, Arte medievale 2, 2008, s. 121-130.

Džurova, A.; Manuscrits grecs enluminés des Archives nationales de Tirana (VIe-XIVe siècles), Études Choisies 1: Texte, Sofya, 2011.

Ehrhard, A.; Überlieferung und Bestand der hagiographischen und homiletischen Literatur der griechischen Kirche von den Anfängen bis zum Ende des 16. Jahrhunderts, vol. II, Leipzig, 1937. 
Eustratiades, S. ve Vatopédinos, A.; Catalogue of the Greek Manuscripts in the Library of the Monastery of Vatopedi on Mt. Athos, Harvard Theological Studies XI, Cambridge, 1924.

Evans, H. C. ve Wixom, W. D. (ed.); The Glory of Byzantium Art and Culture of The Middle Byzantine Era A.D. 843-1261, The Metropolitan Museum of Art-H. N. Abrams, New York, 1997.

Foti, M. B.; "Lo Scriptorium del S.mo Salvatore di Messina”, Scritture, Libri e Testi Nelle Aree Provinciali di Bisanzio. Atti del Seminario di Erice (18-25 Settembre 1988), Biblioteca del "Centro per il collegamento degli studi medievali e umanistici nell'Università di Perugia" 5, Centro italiano di studi sull'alto medioevo, Spoleto, 1991, s. 389-416.

Gkoutzioukostas, A.; "The prefect of Illyricum and the prefect of Thessaloniki”, Byzantiaka 30, 2012-2013, s.45-80.

Grierson, P.; Byzantine Coins, University of California Press, Berkeley, Los Angeles, 1982.

Hägg, T.; "Photius as a Reader of Hagiography: Selection and Criticism", Dumbarton Oaks Papers 53, 1999, s. 43-58.

Hoffmann, K.; The Year 1200 II: A Background Survey, (ed. F. Deuchler), The Metropolitan Museum of Art, New York, 1970.

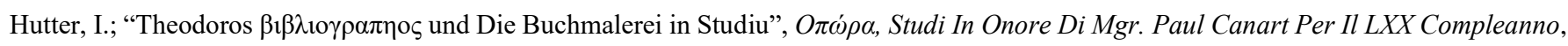
(ed. S. Lucà ve L. Perria), Bollettino Della Badia Greca Di Grottaferrata 51, 1997, s. 177-208.

Jacob, A.; "I più antichi codici greci di Puglia: ovvero un viaggio della paleografia nel paese che non c'è", Studi medievali e moderni 2, 2002, s. 5-42.

Jacoby, D.; "Venetian Commercial Expansion in The Eastern Mediterranean", Byzantine Trade 4th-12th Centuries The Archaeology of Local, Regional and International Exchange, (Papers of the 38th Spring Symposium of Byzantine Studies, St John's College, University of Oxford, March 2004), (ed. M. M. Mango), Ashgate, Surrey, Burlington, 2009, s. 371-393.

Jaeger, W.; Cavarnos, J.; Callahan, V. W.; Gregorii Nysseni Opera ascetica, Gregorii Nysseni Opera VIII.1, Brill, Leiden, 1952.

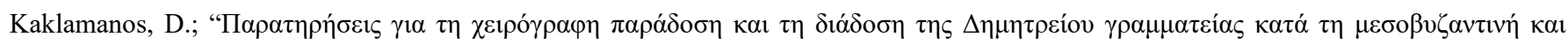

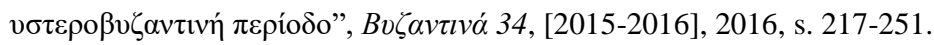

Kaldellis, A.; "Hellenic Afterworlds: The Timarion", Hellenism In Byzantium The Transformationsof Greek Identity and The Reception of The Classical Tradition, Cambridge University Press, New York, 2007, s. 276-282.

Kautzsch, R.; Kapitellstudien. Beiträge zu einer Geschichte des Spätantiken Kapitells im Osten vom vierten bis ins siebente Jahrhundert, Studien zur Spätantiken Kunstgeschichte, Berlin, Leipzig, 1936.

Kaya Zenbilci, İ. Orta Bizans Dönemi Konstantinopolis Manastır Atölyeleri ve Resimli El Yazmaları Üretimi, Basılmamış Doktora Tezi, Ankara Üniversitesi Sosyal Bilimler Enstitüsü Sanat Tarihi Anabilim Dalı, 2017, s. 193-290.

Kazhdan, A.; “Comes”, The Oxford Dictionary of Byzantium I, (ed. A. P. Kazhdan), Oxford University Press, Oxford, 1991, s. 484-485.

Kazhdan, A.; "Eparch”, Oxford Dictionary of Byzantium I, (ed. A. P. Kazhdan), Oxford University Press, Oxford, 1991 , s. 704.

Kazhdan, A.; "Gerokomos", The Oxford Dictionary of Byzantium II, (ed. A. P. Kazhdan), Oxford University Press, Oxford, 1991, s. 848-849.

Kazhdan, A.; "Sirmium", Oxford Dictionary of Byzantium III, (ed. A. P. Kazhdan), Oxford University Press, Oxford, 1991 , s. 1906.

Kazhdan, A.; “Timarion”, Oxford Dictionary of Byzantium III, (ed. A. P. Kazhdan), Oxford University Press, Oxford, 1991 , s. 2085.

Kazhdan, A.; "Vestes", The Oxford Dictionary of Byzantium III, (ed. A. P. Kazhdan), Oxford University Press, Oxford, 1991, s. $2162-2163$.

Kazhdan, A. ve Magdalino, P.; "Referendarios", Oxford Dictionary of Byzantium III, (ed. A. P. Kazhdan), Oxford University Press, Oxford, 1991, s. 1778.

Kazhdan, A. ve Ševčenko, N. P.; "Demetrios of Thessalonike”, Oxford Dictionary of Byzantium I, (ed. A. P. Kazhdan), Oxford University Press, Oxford, 1991, s. 605-606.

Kiilerich, B.; "Picturing Ideal Beauty: The Saints in The Rotunda at Thessaloniki", An Tard 15, 2007, s. 321-336.

Kleinbauer, W. E. "Some Observations on the Dating of S. Demetrius in Thessaloniki”, Byzantion 40, 1970, s. 36-44.

Kleinbauer, W. E.; "The Iconography and the Date of the Mosaics of the Rotunda of Hagios Georgios, Thessaloniki”, Viator 3, 1972, s. 27108.

Koukourtidou-Nikolaidou, E. ve Tourta, A.; Wandering in Byzantine Thessaloniki, Kapon Editions, Atina, 1997.

Kreinina, A.; "The Life of Theophano The Empress: The Slavonic Version of An Unknown Byzantine Orijinal”, Scrinium 7-8(1), 2011-2012, s. $169-230$.

Krueger, D. (ed.); A People's History of Christianity 3: Byzantine Christianity, Fortress Press, Minneapolis, 2010. 
Krumbacher, K.; Geschichte der Byzantinischen Litteratur von Justinian bis zum Ende des Oströmischen Reiches (527-1453), Münih, 1897.

Kurth, J.; "Die Mosaïkinschriften von Salonik”, Mitteilungen des Deutschen Archäologischen Instituts-Athenische Abteilung 22, 1987, s. 463475.

Lemerle, P.; Les Plus Anciens Recueils des Miracles de Saint Démétrius I: le Texte, Paris, 1979.

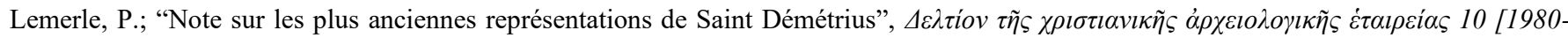

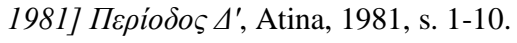

Lucà, S.; “Attività scrittoria e culturale a Rossano: da S. Nilo a S. Bartolomeo da Simeri (secoli X-XII)”, Atti del congresso internazionale su S. Nilo di Rossano. 28 settembre- $1^{\circ}$ ottobre 1986, Rossano, Grottaferrata, 1989, s. 25-73.

Lucà, S. "Dalle collezioni manoscritte di Spagna: Libri originari o provenienti dall'Italia greca medievale", Rivista di Studi Bizantini e Neoellenici 44, 2007, s. 38-96.

MacDougall, B.; "The Festival of St. Demetrios, The Timarion, and The Aithiopika”, Byzantine and Modern Greek Studies 40(1), 2016, s. 136- 150 .

Macrides, R. J.; "Subversion and Loyalty in The Cult of St. Demetrios", Byzantinoslavica LI(2), 1990, s. 189-197.

Macrides, R. J.; “Chartopylax”, The Oxford Dictionary of Byzantium I, (ed. A. P. Kazhdan), Oxford University Press, Oxford, 1991 , s. 416. Magdalino, P.; "Saint Demetrios and Leo VI", Byzantinoslavica LI(2), 1990, s. 198-201.

Marcotte, D. "Une carte inédite dans les scholies aux Halieutiques d'Oppien. Contribution à l'histoire de la géographie sous les premiers paléologues", Revue des études grecques 123, 2010, s. 641-659.

Miller, E.; Catalogue des manuscrits grecs de la Bibliothèque de l'Escurial, Paris, 1848.

Mineva, E.; The Byzantine Hagiographic and Hymnographic Texts on St Parasceve of Epibtae. I, The Byzantine vita of St Parasceve of Epibatae or the vita by "Vasilikos the Deacon”, Publishing Center Boyan Penev, Institute for Literature, Bulgarian Academy of Sciences, Sofia, 2017.

Mirković, M. Sirmium Its History from The First Century AD to 582 AD, Sremska Mitrovica, Novi Sad, 2017.

Matthiae, G.; "La cultura figurativa di Salonicco nei secoli V e VI”, Rivista di Archeologia Cristiana 38, 1963, s. $163-213$.

Nalpantis, D.; Museum of Byzantine Culture Archaeological Guide, Atina, 2018.

Neil, B.; "The Politics of Hagiography in Ninth-Century Rome”, Text and Transmission in Medieval Europe, (ed. C. Bishop), Cambridge Scholars Publishing, Newcastle, 2007, s. 58-75.

Nersessian, S. der; L'Illustration des Psautiers Grecs du Moyen Age II: Londres, Add. 19.352, Bibliothèque des Cahiers Archéologiques 5, Paris, 1970 .

Paschalidis, S. A.; "The Hagiography of The Eleventh and Twelfth Centuries", The Ashgate Research Companion to Byzantine Hagiography I: Periods and Places, (ed. S. Efthymiadis), Ashgate, Farnham, Burlington, 2011, s. 143-171.

Pasqualini, A.; Massimiano Herculius Per Un'interpretazione della Figura e dell'Opera, Roma, 1979.

Paul, A.; "Historical Figures Appearing in Epigrams on Objects”, Poetry and Its Context in Eleventh-Century Byzantium, (ed. F. Bernard, K. Demoen), Ashgate, 2012, s. 89-114.

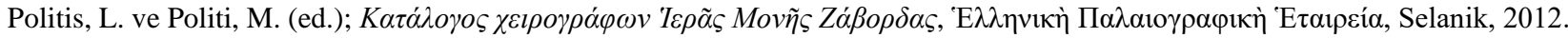

Rapp, C.; "Figures of Female Sanctity: Byzantine Edifying Manuscripts and Their Audience", Dumbarton Oaks Papers 51, 1996, s. 313-345. Sánchez, R. C.; "Historia del texto del Comentario anónimo al Tetrabiblos de Tolomeo", MHNH Revista internacional de investigación sobre Magia y Astrología antiguas 13, 2013, s. 77-198.

Sarris, N.; Classification of finishing tools in Greek bookbinding: establishing links from the Library of St Catherine's Monastery, Sinai, Egypt, cilt 1, Basılmamış Doktora Tezi, University of the Arts, Londra, 2010.

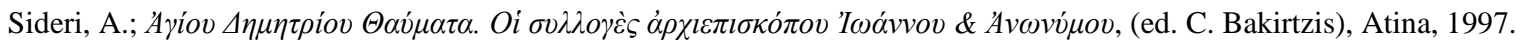

Simonet, J.; "Les variantes communes des versions syriaques, arménienne et latine dans le Discours 41 de Grégoire de Nazianze”, (ed. A. Schmidt), Studia nazianzenica II, CCSG 73, Turnhout, Brepols, 2010, s. 585-604.

Skedros, J. C.; Saint Demetrios of Thessaloniki: Civic Patron and Divine Protector 4th- 7th Centuries CE, Trinity Press International, Harrisburg, 1999. 
Skedros, J. C.; "Shrines, Festivals, and the <Undistinguished Mob>”, A People's History of Christianity 3: Byzantine Christianity, (ed. D. Krueger), Fortress Press, Minneapolis, 2010, s. 81-102.

Skylitzes, J.; A Synopsis of Byzantine History 811-1057, (İngilizceye çev. J. Wortley), Cambridge University Press, Cambridge, 2010.

Spatharakis, I.; The Portrait in Byzantine Illuminated Manuscripts, E. J. Brill, Leiden, 1976.

Spieser, J.-M.; "Inventaires en vue d'un recueil des Inscriptions Historique de Byzance I: Les Inscriptions de Thessalonique”, Travaux et Mémories du Centre de Recherche d'Historie et Civilisation de Byzance 5, 1973, s. 145-180.

Spieser, J.-M.; Théssalonique et ses monuments du IVe au VIe siècle Contribution à l'étude d'une ville paléochrétienne, École Française d'Athènes, Paris, 1984.

Stefec, R. S.; “Aspekte Griechischer Buchproduktion in der Schwarzmeerregion”, Scripta 7, 2014, s. 205-233.

Tafrali, O.; Sur la date de l'église et des mosaïques de Saint-Démétrius de Salonique, Revue Archéologique, $4^{\text {th }}$ Series, 13, Paris, 1909.

Tóth, P.; "Sirmian Martyrs in Exile Pannonian Case-Studies and Re-evaluation of The St. Demetrius Problem", Byzantinische Zeitschrift 103(1), 2010, s. 145-170.

Vickers, M.; "The Date of the Mosaics of the Rotunda at Thessaloniki”, Papers of The British School in Rome 38, 1970, ss. $183-187$.

Vickers, M.; "The Stadium at Thessaloniki”, Byzantion 41, 1971, s. 339-348.

Vickers, M.; "Hellenistic Thessaloniki”, The Journal of Hellenic Studies 92, 1972, s. 156-170.

Vickers, M.; "Sirmium or Thessaloniki? A Critical Examination of The St. Demetrius Legend", Byzantinische Zeitschrift 67(2), 1974, s. 337350 .

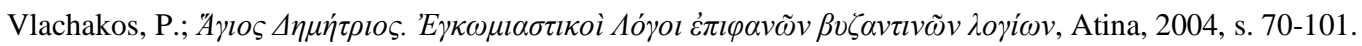

Walter, C.; The Warrior Saints In Byzantine Art And Tradition, Ashgate, Aldershot, Hants, 2003.

Weigand, E.; "Der Kalenderfries von Hagios Georgios in Thessaloniki. Datierung, Ideen-und Kunstgeschichtliche Stellung”, Byzantinische Zeitschrift 39, 1939, s. 116-145.

Woods, D.; “Thessalonica's Patron: Saint Demetrius or Emeterius?”, The Harvard Theological Review 93/3, 2000, s. 221-234.

Woods, D.; “Constantius, Julian, and The Fall of Sirmium”, Exemplaria Classica, Anejo VII, 2016, s.175-191.

\section{Çevrimiçi Kaynakça}

British Library-Digitized Manuscript; “Add MS 19352”, http://www.bl.uk/manuscripts/Viewer.aspx?ref=add_ms_19352_f013r, Londra, Birleşik Krallık, tarih yok [Erişim Tarihi: 25.10.2020].

Dumbarton Oaks Resources Byzantine Seals; "Adrian (sixth/seventh century)"; https://www.doaks.org/ resources/seals/byzantineseals/BZS.1958.106.2760/view, Trustees for Harvard University, Washington D.C., 2020 [Erişim Tarihi: 25.10.2020].

Dumbarton Oaks Resources Byzantine Seals; “John metropolitan of Thessalonica (ca. 1198)", https://www. doaks.org/resources/seals/byzantine-seals/BZS.1958.106.10, Trustees for Harvard University, Washington D.C., 2020 [Erişim Tarihi: 25.10.2020].

Dumbarton Oaks Resources Byzantine Seals; "Leo komes tou Arithmou (tenth/eleventh century", https://www.doaks.org/ resources/seals/byzantine-seals/BZS.1958.106.3423/view, Trustees for Harvard University, Washington D.C., 2020 [Erişim Tarihi: 25.10.2020].

Dumbarton Oaks Resources Byzantine Seals; "Michael vestes and gerokomos (tenth/eleventh century)", https://www.doaks.org/ resources/seals/byzantine-seals/BZS.1947.2.405/view, Trustees for Harvard University, Washington D.C., 2020 [Erişim Tarihi: 25.10.2020].

Dumbarton Oaks Resources Byzantine Seals; "Michael vestes and gerokomos (tenth/eleventh century)", https://www.doaks.org/ resources/seals/byzantine-seals/BZS.1955.1.2547/view, Trustees for Harvard University, Washington D.C., 2020 [Erişim Tarihi: 25.10.2020]. Dumbarton Oaks Resources Byzantine Seals; "Michael vestes and gerokomos (tenth/eleventh century)", https://www.doaks.org/ resources/seals/byzantine-seals/BZS.1955.1.2548/view, Trustees for Harvard University, Washington D.C., 2020 [Erişim Tarihi: 25.10.2020].

Dumbarton Oaks Resources Byzantine Seals; "Peter arcbishop of Thessalonica (eighth century)"; https://www.doaks.org/ resources/seals/byzantine-seals/BZS.1951.31.5.1307/view, Trustees for Harvard University, Washington D.C., 2020 [Erişim Tarihi: 25.10.2020].

Dumbarton Oaks Resources Byzantine Seals; “Sisinnios/Honorios (?) (twelfth century)”, https://www.doaks.org/resources/seals/byzantineseals/BZS.1951.31.5.2611/view, Trustees for Harvard University, Washington D.C., 2020 [Erişim Tarihi: 25.10.2020]. 
DVL-Digivatlib, “Manuscript-Barbr.gr.372”, https://digi.vatlib.it/view/MSS_Barb.gr.372, Biblioteca Apostolica Vaticana, Vatikan.

Pinakes: Textes et Manuscrits Grecs; "Iohannes Thessalonicensis mtr. Miracula S. Demetrii”; https://pinakes.irht.cnrs.fr/notices/oeuvre/9357/, 2016 [Erişim Tarihi: 19.10.2020].

Pinakes: Textes et Manuscrits Grecs; "Hagiographica, Demetrius m. Thessalonicae (S.), Passio metaphrastica", https://pinakes.irht.cnrs.fr/ notices/oeuvre/15317/, 2016 [Erişim Tarihi: 19.10.2020].

The State Hermitage Museum; "Dish Bottom Depicting St Demetrius", https://www.hermitagemuseum.org/wps/ portal/hermitage/digitalcollection/10. + porcelain\%2c+faience\%2c+ceramics/373154, 1998-2020 [Erişim Tarihi: 03.11.2020].

The State Hermitage Museum; "Icon of Saint Warriors George, Theodore, Demetrius ", https://www.hermitagemuseum.org/ wps/portal/hermitage/digital-collection/01.+paintings/487614, 1998-2020 [Erişim Tarihi: 03.11.2020]. 